\title{
JACA, TOULOUSE, CONQUES Y ROMA: LAS HUELLAS DE LOS VIAJES DE DIEGO GELMÍREZ EN EL ARTE ROMÁNICO COMPOSTELANO
}

\author{
Manuel Castiñeiras
}

Universitat Autònoma de Barcelona 

De Compostela hizo entonces un emporio, de su iglesia una de las primeras de la cristiandad, de Galicia un verdadero Estado, tratando de que en su ciudad, en su iglesia y en su tierra todo correspondiese a los destinos que con mano casi regia, les había preparado.

Manuel Murguía, Don Diego Gelmírez $(1898)^{1}$

Con estas emotivas pero contundentes palabras el historiador y pensador gallego Manuel Murguía perfilaba a finales del siglo xix la importancia del primer arzobispo compostelano, Diego Gelmírez (1070?-1140), en la promoción de la sede de Compostela. Más allá de la tendencia a la prosopopeya del autor, común en la historiografía decimonónica, cabe reconocer, sin lugar a dudas, que dicho prelado fue protagonista privilegiado del reinado de tres monarcas castellano-leoneses, del longevo Alfonso vi (1065-1109), de su controvertida hija Urraca de Castilla (1109-1126) y de su nieto, el emperador Alfonso vir (1126-1157). Caber recordar que este último, Alfonso Raimúndez, siendo apenas un niño, había sido coronado como rey de Galicia, en 1111, por el propio Gelmírez en el altar mayor de la Catedral de Santiago, renovado por él tan solo unos años antes.

Prueba de la estrecha vinculación de estos convulsos hechos históricos con el proceso constructivo del monumento jacobeo y el patronazgo de Gelmírez es la inscripción — «ANF(US) REX»—, que se labró, con motivo de la citada coronación del rey-niño, sobre la lastra del Santiago entre cipreses perteneciente al grupo de la Transfiguración y que fue colocada entonces, junto a otros relieves de dicha escena, en el centro del friso de la Puerta de Platerías en 1111 (fig. 1). Tal y como narra la Historia Compostelana (I, 66), el prelado había ungido e impuesto al nuevo monarca las insignias del poder en el nuevo altar mayor jacobeo, sobre la tumba apostólica, haciéndole sentar, simbólicamente, en su cátedra episcopal, convertida así en un improvisado trono real:

1 M. Murguía, Don Diego Gelmírez, cap. xxir, Santiago de Compostela, 1991, p. 86 (1 $1^{\text {a }}$ ed. A Coruña, 1898). 


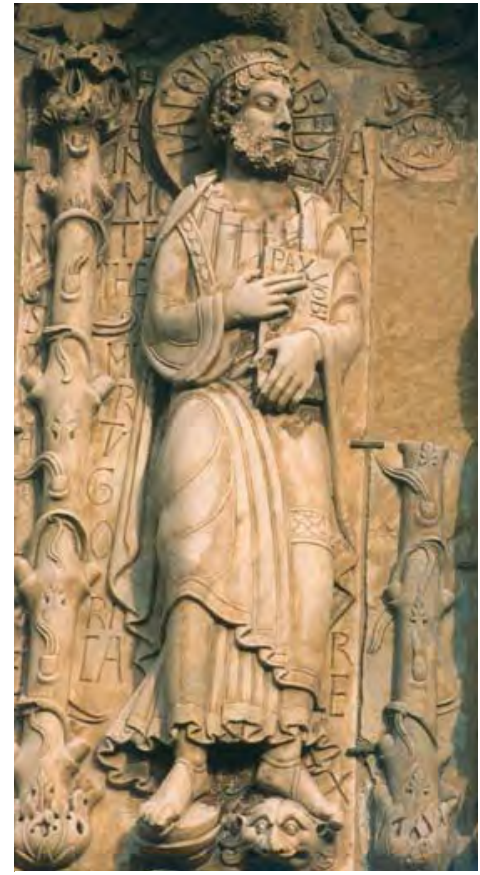

Fig. 1. Catedral de Santiago, fachada sur, frontispicio: Maestro de la Transfiguración, Santiago entre Cipreses, 1103-1111.

Tomándolo el pontífice le condujo con ánimo gozoso ante el altar de Santiago apóstol, donde se asegura que descansa su cuerpo, y allí, según normas de los cánones religiosamente le ungió como rey, le entregó la espada y el cetro y, coronado con diadema de oro, hizo sentar al ya proclamado rey en la sede pontifical ${ }^{2}$.

Con ello Gelmírez estaba imitando el rito de la coronación imperial que se realizaba entonces al amparo de la tumba apostólica por excelencia: la basílica de San Pedro de Roma ${ }^{3}$. De hecho, él no solo había visitado la ciudad papal en dos ocasiones, en 1100 y en 1105, para adquirir nuevos privilegios para él y para su sede, sino que había recibido, entre los años 1109 y 1111, el regalo de una colección canónica dedicada, el Polycarpus, en la que se exponía con claridad una de las bases fundamentales de la ideología de la reforma de Gregorio viI (1073-1085) ${ }^{4}$ : el papel «tutelar» que había de ejercer el sacerdocium con respecto al regnum en los asuntos del poder temporal. De esta manera, la labra del nombre del nuevo monarca, a modo de aclamación, junto a la figura de Santiago en el momento de su máximo esplendor como apóstol — pues éste es testigo privilegiado de la Transfiguración de Cristo-, hay que entenderlo también como la férrea voluntad del prelado de exaltar la sede jacobea, en la que el sacerdocium tutela al regnum, siguiendo así los dictados de la Reforma Gregoriana, a la cual Gelmírez se había sumado

2 Historia Compostelana, I, 66, E. Falque Rey (trad.), Madrid, 1994, p. 174 (a partir de ahora citada como HC, trad. cit.).

3 Ese mismo año, en 1111, el Papa Pascual II coronaba al emperador Enrique v en San Pedro del Vaticano. Cfr. D. F. Glass, Studies in Cosmatesque Pavements, British Archeological Reports, International Series, 82, 1980, pp. 51-52, 121-122.

4 Véase nota 36. 
con entusiasmo 5 . En este sentido, vuelven a ser evocadoras las palabras escritas por Manuel Murguía a propósito de la figura del prelado:

La ceremonia tuvo lugar en la basílica. La vasta y hermosa capilla mayor llenose de potestades de la tierra y de príncipes de la iglesia. Llegó el momento en que el infante, pasando como si dijéramos de la prisión al trono, fue ungido por D. Diego, quien dijo la misa y ciñó la corona al nuevo monarca. Todo ello en medio del mayor regocijo, dando motivo a las más dulces esperanzas, y a las seguridades de que en aquel momento, amanecían en Galicia días de ventura y prosperidad no conocida ${ }^{6}$.

No obstante, la presente contribución no pretende desentrañar la "personalidad política» de Gelmírez, pues es tarea de otros autores en la presente publicación, sino más bien su perfil biográfico como promotor de las artes y, en particular, la realización en la primera década de su obispado de un lujoso nuevo altar mayor de la Catedral de Santiago así como de las dos fachadas monumentales del transepto. Con ello, tal y como recordaba Manuel Murguía, Compostela se colocaba a la vanguardia del arte románico de su tiempo:

El templo apostólico, que había empezado a labrarse antes de ascender Gelmírez a la sede, él lo ayudó a levantar del todo, él lo adorno generosamente. Cuando vuelto a la patria, presentes en la memoria las grandes obras de arte que había admirado al recorrer Francia,

5 La lastra de Santiago entre cipreses de Platerías es un verdadero visual manifesto de la teoría gregoriana en clave compostelana, tal y como he expuesto en trabajos precedentes: el Apóstol Santiago, cuya casa gobierna Gelmírez, tutela una monarquía que desde el siglo vin había vinculado el ideario de la Reconquista a la figura del Apóstol. Años más tarde, Gelmírez llevará a cabo, en otro contexto, toda una serie de acciones y proyectos para afianzar esa alianza. Así, concederá a Alfonso vir el título de canónigo (1127) con el objeto de forzarle a elegir como lugar de sepultura la basílica del Apóstol y convertirlo plenamente en un rex sacerdos. A ese mismo ideario corresponde el ambicioso proyecto de colección documental del Tumbo A, realizado pocos años después (1129-1134), en el que se ilustra una serie de «retratos» de reyes favorecedores de la basílica jacobea, que se inicia con una miniatura del hallazgo del sepulcro del Apóstol y termina con el retrato del emperador Alfonso vir. En casi todas las estampas que encabezan los documentos de donación se repite, hasta la saciedad, la fórmula del nombre del monarca y su título regio, como años antes se había hecho en la lastra de Platerías. Véase: M. Castińeiras, «Didacus Gelmirius, patrono de las artes. El largo camino de Compostela: de periferia a centro del Románico», en M. Castińeiras (dir.), Compostela y Europa. La historia de Diego Gelmirez, Skira-Xunta de Galicia, Milán, 2010, pp. 32-97, espec. 83-84.

6 Murguía, Don Diego Gelmírez, cap. XII, p. 46. 
Italia y en especial Roma: ante los ojos las esplendideces del culto en el monasterio de Cluny, trató de realizar en Santiago algo de lo que había visto y presenciado, poniendo en todo ello al templo apostólico, al igual de los más notables del orbe católico 7 .

Mostrar esta visión del personaje fue, además, el objetivo principal de la exposición celebrada en el año 2010, bajo los auspicios del Xacobeo de la Xunta de Galicia, Compostela y Europa. La historia de Diego Gelmírez, con sede itinerante en el Musée des Monuments Français (París), en el Braccio di Carlomagno (Città del Vaticano) y en el monasterio de San Martín Pinario (Compostela) ${ }^{8}$. Con ella se trató de poner de manifiesto el papel fundamental de la Compostela del año 1100 en la construcción del arte románico europeo. En mi opinión, no cabe duda alguna de que el protagonista de este proceso, a través del cual Santiago se convirtió en agente activo (y no pasivo), fue el entonces obispo Diego Gelmírez, el cual realizó una serie de viajes en los primeros años de su gobierno en busca de la mayor dignidad de su Iglesia. Gracias a ello fue capaz de conferirle a ésta, en un breve espacio de tiempo, una nueva imagen sin parangón en el Occidente europeo.

La originalidad del proyecto, Compostela y Europa. La historia de Diego Gelmírez, se basaba en el desarrollo de una hipótesis de trabajo que tenía un cierto riesgo: la interpretación de un hecho histórico — los viajes del comitente y de su séquito- como un verdadero motor artístico que explicase el carácter internacional de los nuevos talleres activos en Compostela en la primera década del siglo XII. Dos obras, lamentablemente destruidas, la Porta Francigena de la Catedral de Santiago (fig. 2), realizada entre 1101 y 1111, y el mobiliario litúrgico del altar mayor de la basílica (fig. 3), llevado a cabo entre 1105 y 1106, constituyeron en gran parte la base de dicha argumentación. Por ello, su reconstrucción virtual, realizada por primera vez con motivo de dicha muestra ${ }^{9}$, tomó como punto de partida el trabajo previo que había realizado en su día mi maestro, el profesor

7 Murguía, Don Diego Gelmírez, p. 86.

8 M. Castiñeiras (ed.), Compostela y Europa. La historia de Diego Gelmírez, Skira-Xunta de Galicia, Milán-Santiago de Compostela, 2010.

9 Compostela y Europa. La historia de Diego Gelmírez (DVD) contiene los vídeos —Los tiempos del obispo Diego Peláez y Los viajes de Diego Gelmírez — así como las reconstrucciones virtuales del Castillo de Torres de Oeste (Catoira, Pontevedra), de la Porta Francigena y del Altar Mayor de la Catedral de Santiago de Compostela. 


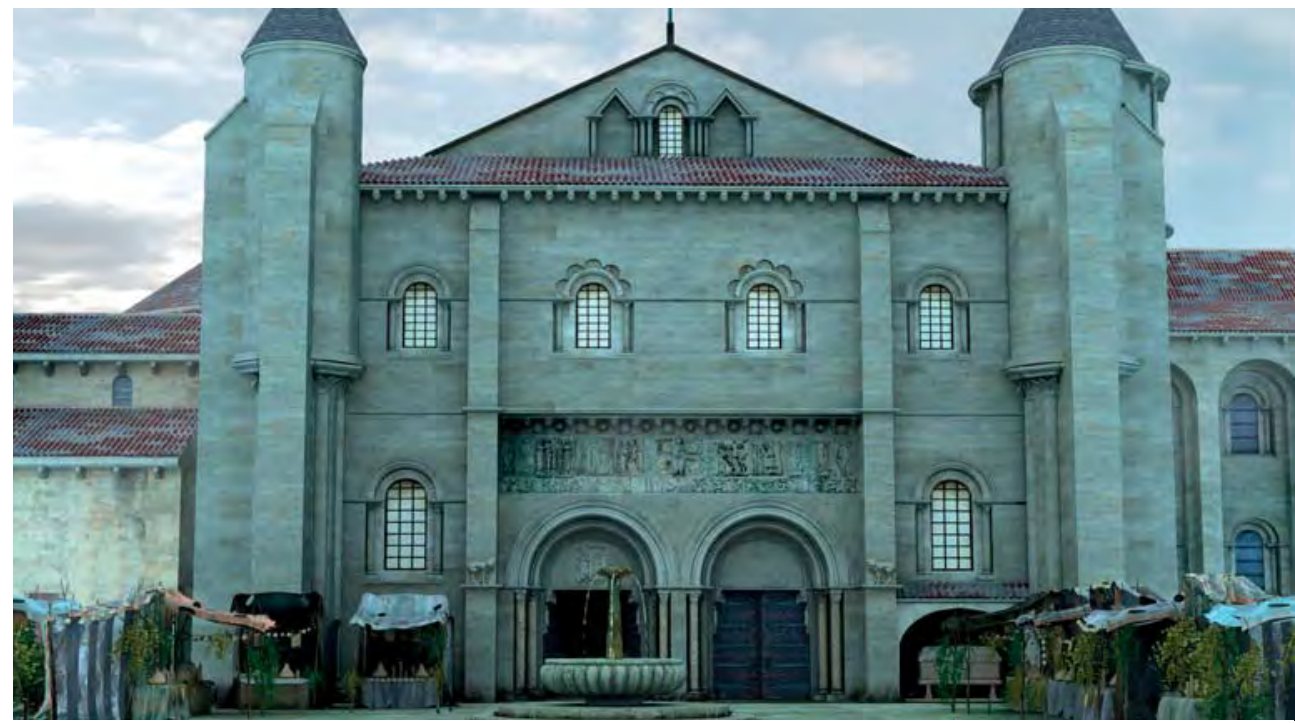

Fig. 2. Porta Francigena de la Catedral de Santiago (Reconstrucción hipotética en 3D), 2010. Asesor científico: Manuel Castiñeiras. Producción Técnica: Tomas Guerrero-Magneto Studio. (C) S.A. de Xestión do Plan Xacobeo, Santiago de Compostela.

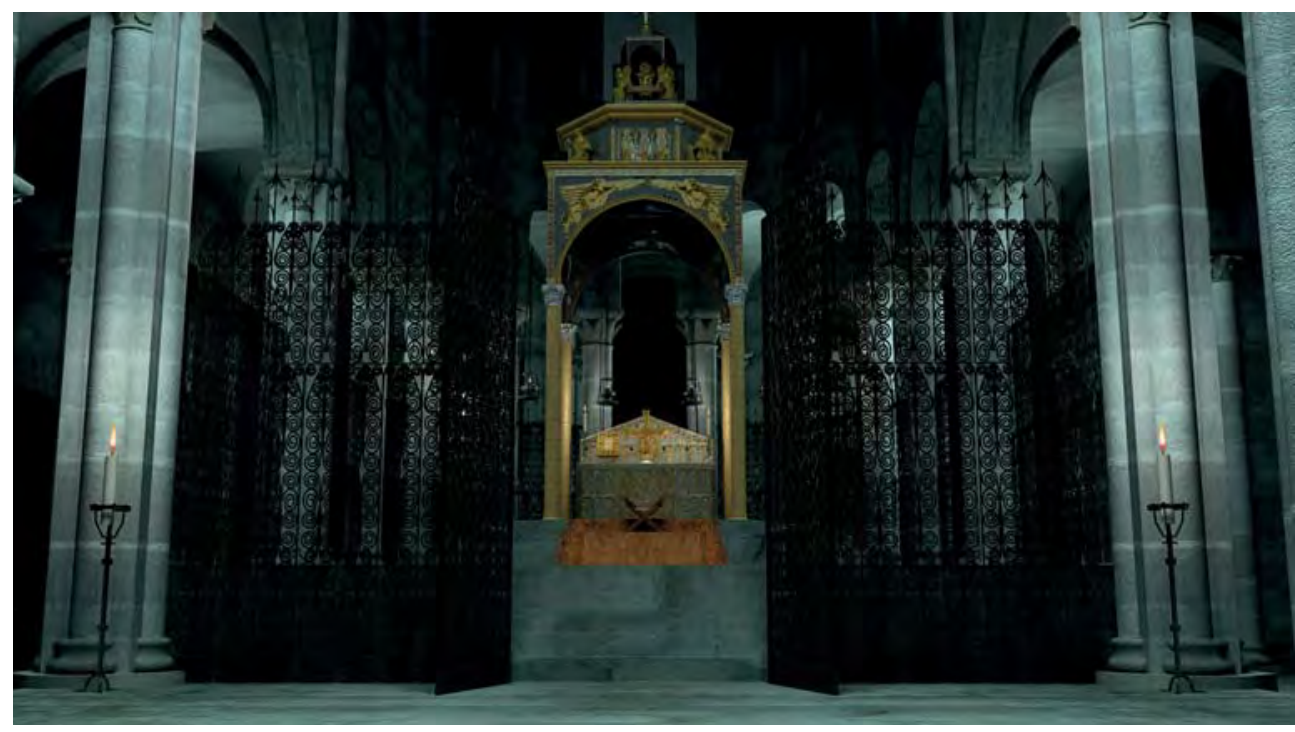

Fig. 3. Altar mayor de la Catedral de Santiago en tiempos de Diego Gelmírez (Reconstrucción hipotética en 3D), 2010. Asesor científico: Manuel Castińeiras. Producción Técnica: Tomas Guerrero-Magneto Studio. (C) S.A. de Xestión do Plan Xacobeo, Santiago de Compostela. 
Serafín Moralejo ${ }^{10}$. No obstante, durante la aplicación de las nuevas tecnologías digitales, se pudo efectuar toda una serie de nuevas aportaciones, con respecto al trabajo de Moralejo, que ayudaron a resolver algunas cuestiones fundamentales, tales como las texturas de los materiales, la organización de los espacios o la disposición de objetos y figuras. Para ello se volvieron a analizar las fuentes textuales en las que se describen dichos monumentos —el Liber Sancti Lacobi y la Historia Compostelana - y se intentó completar la información tanto con el material arqueológico llegado hasta nosotros como con la comparación con otros monumentos coetáneos ${ }^{11}$.

Otro de los objetivos de la exposición era el de «revisitar» el viejo concepto de Arthur Kinsley Porter sobre el denominado «arte de los Caminos de Peregrinación» así como de su obsoleto concepto de «influencia». El autor americano parangonaba la Peregrinación a Compostela con un gran río, que desembocaba en el mar de Santiago y estaba formado por muchos afluentes, cuyas fuentes venían desde las más recónditas regiones de Europa ${ }^{12}$. Esta bella y sugerente metáfora le otorgaba, sin embargo, un papel pasivo a Compostela, ya que la convertía en un santuario afectado de «influencia» — en el sentido italiano de la palabra influenza como enfermedad contagiosa (gripe)—, de otros centros europeos cuyos artistas itinerantes se convertían así en los protagonistas. Por el contrario, con la dimensión europea del proyecto sobre Gelmírez se quiso reclamar el papel de Compostela como agente activo en este proceso a través de las elecciones de su comitente, Diego Gelmírez y de sus viajes.

10S. Moralejo, «La primitiva fachada norte de la catedral de Santiago», Compostellanum, xiv, 4, 1969, pp. 623-668; "Ars Sacra et sculpture romane monumentale: le trésor et le chantier de Compostelle», Les Cahiers de Saint-Michel de Cuxa, 11, 1980, pp. 189-238.

11 Los criterios seguidos en dichas reconstrucciones se explican, con minuciosidad, en: M. Castiñeiras y V. Nodar. «Reconstruyendo la Porta Francigena de la Catedral de Santiago: materiales multimedia para una exposición de arte románico", Románico. Revista de arte de amigos del románico (AdR), 10, 2010, pp. 83-95; «Para una reconstrucción del altar mayor de Gelmírez: cien años después de López Ferreiro», Compostellanum, 55, 2010, pp. 575-640. Cfr. M. Castiñeiras, «La Porta Francigena: una encrucijada en el nacimiento del gran portal románico", Anales de Historia del Arte, volumen extraordinario, diciembre 2011, pp. 93-122, esp. pp. 95-103 (Alfonso VIy el arte de su época, J. Martínez de Aguirre, M. Poza Yagüe [eds.], Madrid, 2011).

12A. K. Porter, Romanesque Sculpture of the Pilgrimage Roads, I, Boston, 1923, p. 175. Para una revisión del concepto de cultura agonística y de intercambio, formulada por A. K. Porter en 1923 con respecto al arte de los Caminos de Peregrinación, remito a mi contribución: "Compostela, Bari y Jerusalén: tras las huellas de una cultura figurativa en los Caminos de Peregrinación», Ad Limina. Revista de Investigación del Camino de Santiago y de las Peregrinaciones, I, 2010, pp. 15-51. 
De hecho, Compostela en el año 1100 era todavía una meta situada en la periferia de Europa, que en pocos años habría de convertirse en un centro artístico de primer orden. La red de caminos que conducía a Compostela sirvió a Gelmírez y a su séquito para acceder a otros centros haciendo, en realidad, «una peregrinación al revés»: de Compostela a Toulouse, a Conques, a Cluny, a Lucca o a Roma (fig. 4). Cada uno de estos lugares permitió plantear nuevos retos en la construcción y definición del gran centro de peregrinación de Compostela.

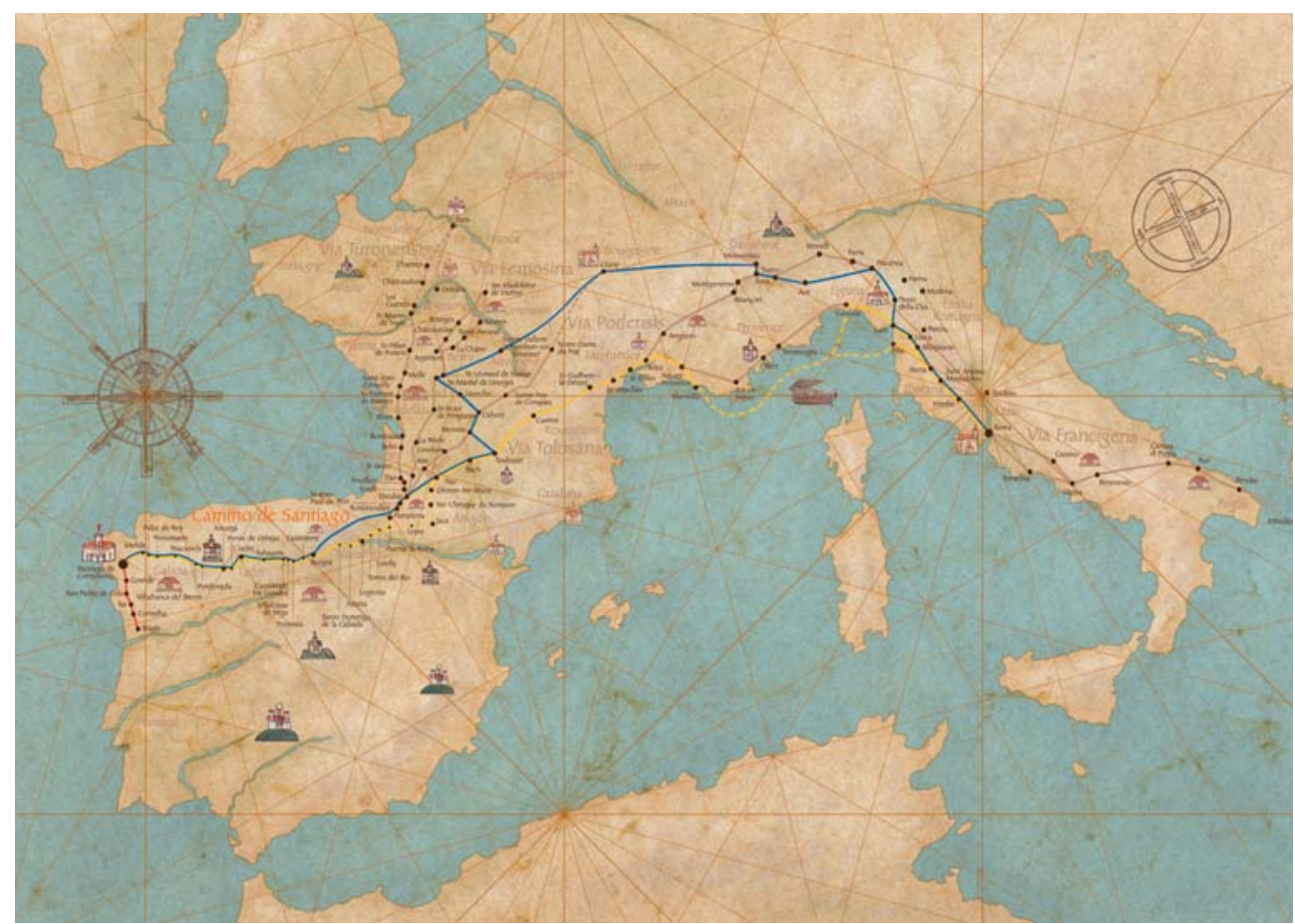

Fig. 4. Itinerarios de los viajes de Diego Gelmírez a Roma en 1100 y 1105. Realizado bajo la dirección científica de M. Castińeiras para la Exposición Compostela y Europa. La historia de Diego Gelmírez, París-Roma-Santiago, 2010.

En este punto sería oportuno recuperar, sin embargo, la idea de Porter de la existencia entonces de una cultura «agonística», de la competencia y del intercambio, propia del fenómeno de la peregrinación. Pero, en contra de lo que pensaba Porter, este intercambio no fue inconsciente sino consciente; fue sobre todo el producto de las elecciones y del empeño de un comitente: Diego 
Gelmírez. El obispo es recordado, de hecho, en los textos contemporáneos bien como sapiens architectus ${ }^{13}$, en el pasaje de la Compostelana que hace referencia a la elevación del gigantesco transepto de la catedral, bien como autor que peregit opus — «llevó a cabo la obra»—, en el epígrafe del frontal de plata del altar mayor ${ }^{14}$.

En definitiva, gracias a sus viajes en busca de nuevas dignidades y referentes, Compostela se sumó definitivamente a la vanguardia del arte europeo alcanzando, como centro creador del románico pleno, un lugar similar al de la Toulouse de la Porte Miègeville, al Conques del abad Bégon (1087-1107), al Cluny del abad Hugo (1024-1109), a la Módena de Matilde Toscana (1036-1115) o la propia Roma papal. En este sentido, no hay que olvidar que la personalidad de Gelmírez es fascinante ya que él, como hombre pragmático e hijo de un guerrero, supo aprovechar los ańos iniciales de su episcopado, entre 1100-1112, para expresar, sin ambages, su credo estético e ideológico. Este consistía, en parte, en un rechazo a los usos de la vieja tradición «hispánica» en la sede compostelana así como de su anticuado aspecto. Por ello Gelmírez no dudó en adherirse, con entusiasmo, a los principios de la reforma gregoriana y buscó en Roma el futuro de Compostela. Dicha estrategia se hace absolutamente explícita en la creación de un nuevo cabildo de canónigos regulares, que substituía a la obsoleta magna congregatio sancti Iacobi, con el objetivo de eliminar cualquier vestigio de los usos de la liturgia hispánica e imponer así los romanos, llegando incluso a crear un colegio de siete cardenales a imitación de las basílicas mayores de la Ciudad Eterna. No dudó tampoco en 1105, tras una larga discusión con el sector más conservador del cabildo, en demoler y ocultar, bajo el nuevo pavimento románico, la cabecera de la basílica del siglo ix con el viejo edículo apostólico de

13 HC, I, 78, 2, trad. cit., p. 189.

14 Liber sancti Iacobi. "Codex Calixtinus», v, 9, A. Moralejo, C. Torres y J. Feo (trads.), Santiago, 1951, pp. 566-567 (a partir de ahora citado como cc). Fundamentales para entender el perfil de Gelmírez como comitente de las artes son los trabajos de J. Filgueira Valverde («Gelmírez, constructor», en Historias de Compostela, Vigo, 1982, pp. 37-75) y de S. Moralejo («El patronazgo artístico de Diego Gelmírez (1100-1140): su reflejo en la obra e imagen de Santiago", en Pistoia e il Cammino de Santiago. Una dimensione europea della Toscana medioevales. Atti del Convegno Internazionale di Studi, Pistoia, 28-30 settembre 1984, Nápoles, 1987, pp. 245-272. 
Santiago el Mayor ${ }^{15}$, para años más tarde, en 1112, arrasar definitivamente, en la zona del transepto y naves, toda traza del antiguo edificio.

\section{LA TRASCENDENCIA DE LAS FACHADAS DEL CRUCERO COMPOSTELANO}

Cabe recordar que, con la elevación de los accesos principales del transepto compostelano - la primitiva Porta Francigena (fig. 2) y Platerías (fig. 5)_, Compostela pasa, entre 1101 y 1111 , de periferia al centro del arte románico europeo. De hecho, el amplio programa iconográfico de sus dos fachadas monumentales comparte experiencias con las obras más importante de la época: la Porte Miègeville de Saint-Sernin de Tou-

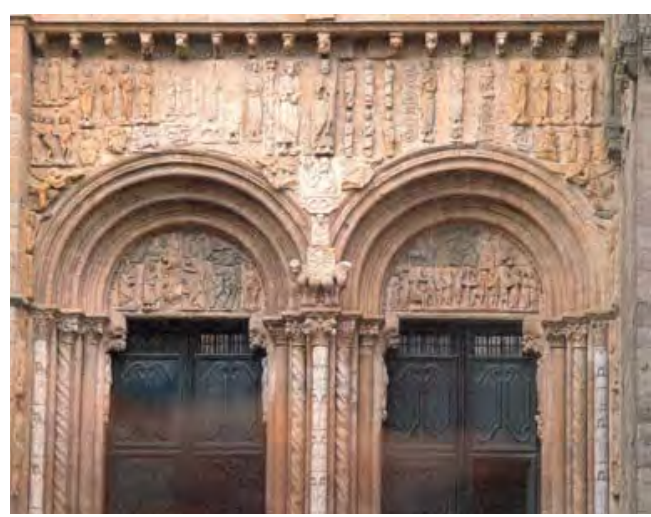

Fig. 5. Catedral de Santiago, brazo sur del transepto, fachada de Platerías, 1103-1111. louse (ca. 1100-1105), el Conques del abad Bégon III (1087-1107) y su Portal Occidental, posiblemente comenzado a inicios del siglo XII, las puertas de la Catedral de Módena (ca. 1099-1106) o las experiencias del arte de la Reforma Gregoriana de la Roma papal. No obstante, dos hechos nos han impedido valorar, en su justa medida, la contribución de los talleres activos en Santiago a inicios del siglo XII a la historia del portal historiado frente a los citados ejemplos coetáneos: por una parte, la destrucción entre 1757

15 HC, I, 18, trad. cit, p. 107. Para un análisis de las importantes «decisiones» estético-simbólicas de Diego Gelmírez, que arrasó la imagen "hispánica» del santuario «asturiano» en beneficio de un monumento puesto al día y con claros manifiestos reformistas-romanos tanto en el altar como en las fachadas del transepto, véase: M. Castińeiras, «Roma e il programma riformatore di Gelmírez nella cattedrale di Santiago", en A. C. Quintavalle (ed.), Medievo: immagini e ideologie. v Convegno Internazionale di Studi, Parma, 23-27 settembre 2002, Parma-Milán, 2005, pp. 211-226; Ídem, «Diego Gelmírez, un committente viaggiatore: dalla Porta Francigena all'altare Maggiore della Cattedrale di Santiago», en A. C. Quintavalle (ed.), Medievo: i committenti. XIII Convegno Internazionale di Studi. Parma, 21-26 settembre 2010, Parma-Milán, 2011, pp. 268-280. 


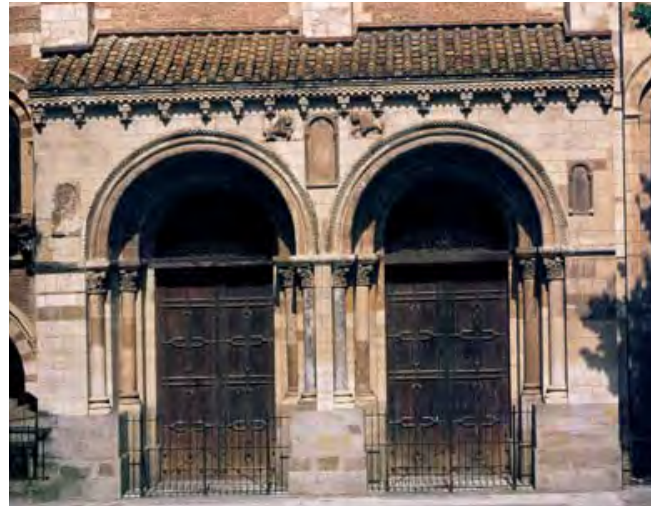

Fig. 6. Basílica de Saint-Sernin de Toulouse, brazo sur del transepto: Porte des Comtes, 1080-1090. y 1758 de la primitiva Porta Francigena; y, por otra, la existencia en la concepción de Platerías de algunos desajustes entre traza arquitectónica y decoración, a la que se suma una larga historia de asedios, restauraciones y remociones.

Desde un punto tipológico, las fachadas del transepto compostelano se han puesto siempre en directa relación con las de la basílica de Saint-Sernin de Toulouse, en particular, con la Porte des Comtes (ca. 1080-1090)

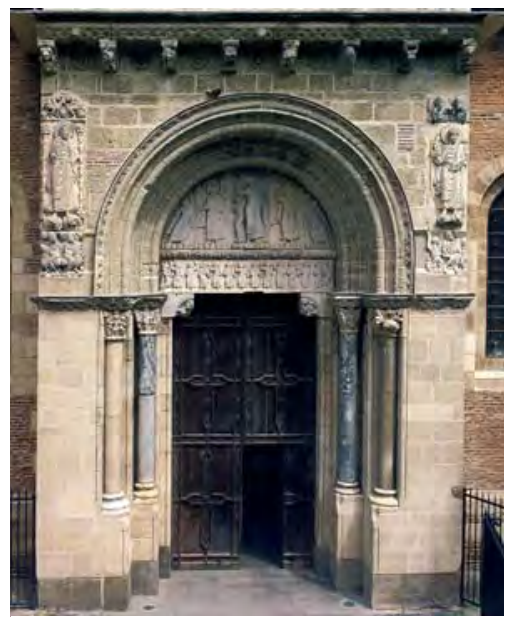

Fig. 7. Saint-Sernin de Toulouse, cuerpo de las naves, lado sur: Porte Miègeville, ca. 1100-1105. (fig. 6), por su estructura de puerta bífora abocinada, con capiteles historiados, decorada con relieves de enjuta en el frontispicio y coronada por una cornisa de canes figurados. A estos elementos arquitectónicos figurados se suman, años más tarde, en la Porte Miegèville (ca. 1100-1105) ${ }^{16}$, otros elementos esculturados como mochetas, tímpano y metopas (fig. 7). En la Porta Francigena existía, además, siguiendo el modelo de la Porte des Comtes, una especie de arcosolio exterior — en el lado derecho de la fachada (fig. 2) - que albergaba el sarcófago del conde de Galicia, Raimundo de Borgoña, fallecido en $1107^{17}$.

16 Para la cronología de las puertas tolosanas remito al novedoso trabajo de Daniel y Quitterie Cazes, Saint-Sernin de Toulouse. De Saturnin au chef d'oeuvre de l'art roman, Editions Odyssée, Toulouse, 2008.

17 J. Puente Míguez ha identificado el arco, todavía visible, que actualmente hace de bóveda de la sacristía de Santa Catalina, "El sepulcro del Conde don Raimundo de Borgońa en la Catedral de Santiago», en Estudios sobre patrimonio artístico. Homenaje del Departamento de Historia del Arte y de la Facultad de Geografia e Historia de la Universidad de Santiago a la Prof. Dra. M. a del Socorro Ortega Romero, Santiago de Compostela, 2002, pp. 83-95. 


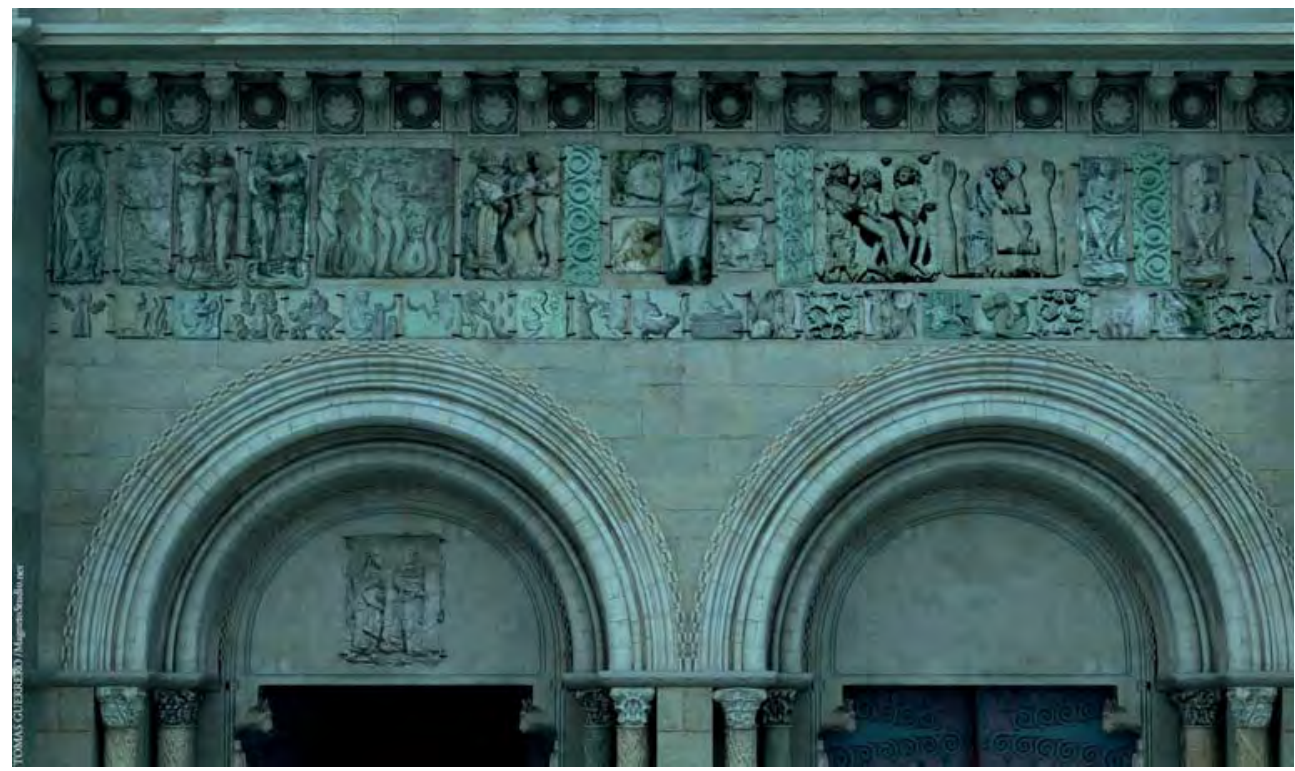

Fig. 8. Reconstrucción 3D de la Porta Francigena: frontispicio, 2010.

No obstante, con respecto a Toulouse, las portadas compostelanas (1101-1111) fueron un verdadero laboratorio de experiencias, en el que se desarrollaron nuevas fórmulas. En primer lugar, cada uno de elementos arquitectónicos que las conformaban fue susceptible de figuración historiada, con una gran variedad de formatos que abarcaba, como en Toulouse, capiteles, mochetas, enjutas, tímpano, canes y metopas, pero que a la vez incorporaba novedades como columnas historiadas, placas figuradas de jamba y frisos narrativos. En segundo lugar, las fachadas compostelanas hicieron crecer el espacio de los frontispicios (fig. 8), con el objeto de convertirlos en verdaderos frisos narrativos o frontis de estatuas. Es en Italia, y no en Francia, donde se encuentran las primeras formulaciones de estos formatos: si en la Catedral de Módena, entre 1099 y 1106, el taller de Wiligelmo realizaba un friso del Génesis para cubrir la entrada principal del edificio (fig. 9), en la de Cremona, entre 1107 y $1117^{18}$, ese mismo taller colocaba cuatro profetas

18Con respecto a las fechas de Módena y Cremona, cfr. A. C. Quintavalle, Willigelmo e Matilde. L'officina romanica, Milán, 1991. Véase también la revisión del tema por parte de D. F. Glass, The Sculpture of Reform in North Italy, ca. 1095-1130. History and Patronage of Romanesque Façades, Bodmin, Cornwall, 2010. 
que flanqueaban, como en la primitiva Porta Francigena y Platerías, la entrada central de la fachada (figs. 10-11). Por último, para las columnas figuradas compostelanas, sobre todo en el caso de la Francigena, los marmolistas romanos que elaboraron a finales del siglo xi las columnas salomónicas de San Carlo a Cave (Lacio) y de Trinità dei Monti (Roma) parecen haber sido el punto de referencia de Compostela ${ }^{19}$.

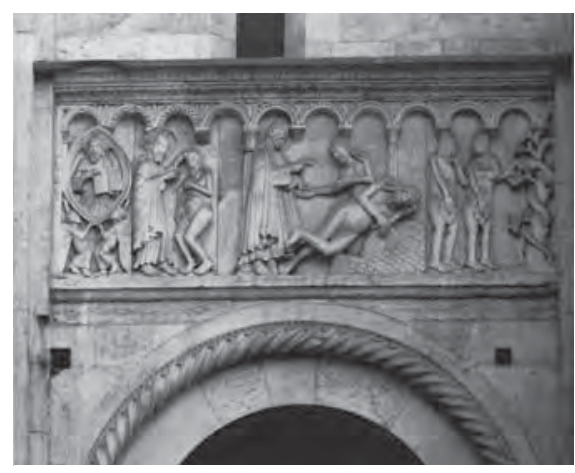

Fig. 9. Catedral de Módena, fachada occidental: Wiligelmo, friso del Génesis, ca. 1099-1106.

Fig. 10. Catedral de Santiago, fachada sur (Platerías), ingreso izquierdo, jamba izquierda: Maestro de las Tentaciones, Moisés, 1103-1105.

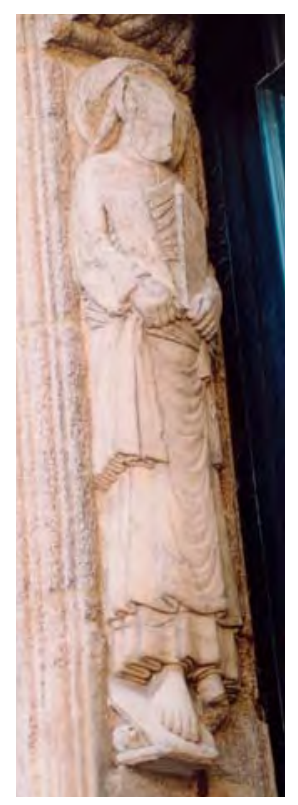

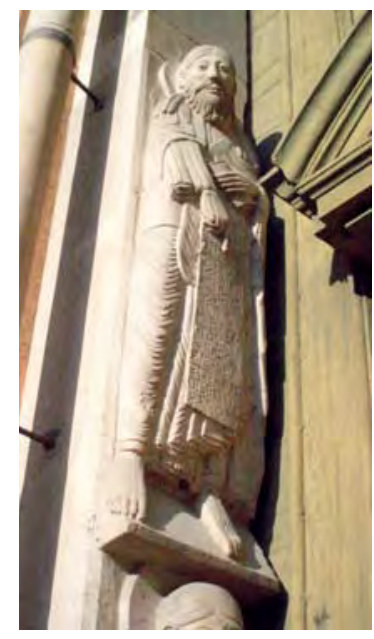

Fig. 11. Catedral de Cremona, fachada occidental, jamba izquierda: Wiligelmo, Jeremías, 1107-1117.

Desde una perspectiva más temática y programática, las fachadas compostelanas presentan un modo genuinamente narrativo, fresco y directo, que no duda en incorporar lo profano a la historia bíblica, como en el Portal Occidental de Santa Fe de Conques ${ }^{20}$. De hecho, este lenguaje figurativo animado y

19Así lo defendí en: «Roma e il programma riformatore». Véase también: V. Nodar, "Colonne salomoniche della chiesa della Santissima Trinità dei Monti a Roma e di San Carlo a Cave», Compostela y Europa, fichas cat. n. ${ }^{\circ}$ 19-20, pp. 346-348.

20 M. Castiñeiras, «Da Conques a Compostella: retorica e performance nell'era dei portali parlanti», en A. C. Quintavalle (dir.), Medievo: Immagine e Memoria, Atti del XI Convegno Internazionale di Studi, Parma, 23-28 settembre 2008, Electa-Università degli Studi di Parma, Milán-Parma, 2009, pp. 233-251; "Antes de los medios de comunicación de masa: la "vocación” parlante del arte medieval», en J. A. Iglesias-Fonseca (ed.), Communicatio: un itinerari històric, Murcia, 2013, pp. 21-41. 
desenfadado, propio de grandes centros de peregrinación, adquiere en Compostela y Conques un carácter tan monumental que convierte a sus portales en verdaderos movie marquee (marquesinas de cine), tal y como en su día sugirió S. Moralejo. Sin embargo, con respecto a Conques, Compostela hace explícita su adhesión a los principios del arte de la Reforma Gregoriana empleando fórmulas similares a la de los monumentos italianos. Como en el Génesis de Módena, donde Dorothy Glass ha sugerido una inspiración en el fronstipicio de una Biblia Atlántica como la del Panteón ${ }^{21}$, en la Porta Francigena el ciclo de Adán y Eva posiblemente seguía el frontispicio de una Biblia carolina, como la de Tours ${ }^{22}$. Del mismo modo, como en Módena o Roma, se detectan referencias explícitas a la Antigüedad paleocristiana, bien a través del conocimiento de las composiciones de los sarcófagos antiguos — ciclo de la Pasión de Platerías—, bien a través de la cita de genuinos motivos decorativos, como los roleos de vid que cubren todavía las lastras verticales del frontispicio de Platerías o las célebres columnas con putti vendimiadores de la primitiva puerta norte ${ }^{23}$.

\section{EL VIAJE COMO MOTOR ARTÍSTICO}

¿Cómo explicar pues el gran salto hacia delante que supusieron las fachadas compostelanas con respecto a las experiencias previas de los talleres activos en el Camino de Santiago o de la propia geografía europea? Con toda probabilidad, la clave está en los viajes emprendidos por Diego Gelmírez y miembros del la curia compostelana en los primeros ańos del siglo XII (fig. 4). En dos ocasiones Gelmírez recorrió el Camino Francés en España y parte de las vías de peregrinación francesas, camino de Roma, en busca de nuevas dignidades para él y su diócesis. Del primero, realizado en 1100 , con apenas 30 ańos, no sabemos casi nada, salvo

21 D. F. Glass, «Leggendo il Genesi nelle sculture della cattedrale di Modena», en Arturo Calzona (dir.), Matilde e il tesoro dei Canossa: tra castelli, monasteri e città, Milán, 2008, pp. 176-187, pp. 179, 182, fig. 7. 22 M. Castińeiras, «Didacus Gelmirius», p. 66. Me refiero, en concreto, a la escena de la condena al trabajo de nuestros primeros padres, tras la Expulsión del Paraíso, que, en mi opinión, seguía fórmulas iconográficas muy similares a las de la Biblia carolingia de Tours. Prueba de ello es la existencia de una lastra con Eva amantando a Caín, procedente de la puerta norte, la cual posiblemente hacía juego con otra con la representación de Adán cavando la tierra, que no se ha conservado.

23 M. Castiñeiras, «Roma e il programma riformatore». 
que fue ordenado subdiácono en la Ciudad Eterna el 18 de marzo de 1100, tal y como recoge la Historia Compostelana (I, viI, 1-2) 24 . Cabe suponer que Gelmírez hubiese emprendido para ello un largo viaje hasta Puente la Reina y de allí tomase el tramo aragonés que, pasando por Jaca, conectaba con la via tolosana, para llegar a la ciudad de Toulouse.

Aunque esta primera visita a la capital de Languedoc es hipotética y no está contrastada en fuentes directas, algunos indicios permiten aventurarnos en la misma. En primer lugar, la ciudad se encontraba entonces en plena efervescencia artística, ya que en 1096 se había consagrado el altar mayor de Saint-Sernin y se estaban comenzando a delinear hacia 1100 las trazas de lo que sería la Porte Miègeville. No hay que olvidar que en su génesis confluían, a tres bandas, los estilos del recién terminado claustro de Moissac (1100), las experiencias del taller de la Catedral de Jaca (1080-1094) y los derivados del maestro Guilduino $(1096)^{25}$. En aquellos momentos, entre 1100 y 1102, según se documenta en el cartulario de Saint-Sernin ${ }^{26}$, ocupaba el puesto de preboste o prior (praepositus) de la comunidad de canónigos un tal Munio, hombre de destacada formación intelectual, a quien tanto Daniel como Quitterie Cazes han atribuido, además de la elevación del desaparecido claustro del sector norte, la posible génesis, en su entorno, del programa de la Porte Miègeville ${ }^{27}$. Su origen navarro y sus vinculaciones con la sede de Pamplona, gracias a las posesiones que en 1086 el obispo Pedro de Anduque y el rey Sancho Ramírez habían donado a la comunidad de Saint-Sernin en Artajona (Navarra), lo convertían en un personaje idóneo para ser visitado por Gelmírez y su séquito. De hecho, quizás la presencia de Munio en Toulouse pudiera ayudar a entender alguno de los fluidos intercambios en la época entre los talleres del reino de Navarra y Aragón, Galicia y el Languedoc. Me refiero, por supuesto, a la presencia de algunos elementos del taller de Jaca en Toulouse, tanto en la tribuna del

24 Historia Compostelana, I, 7, 1-2, trad. cit., pp. 85-86.

25 H. Pradalier, "Saint-Sernin de Toulouse au Moyen Âge», en 154 Congrès Archéologique de France. Toulousain et Comminges. 1996. Société Français d'Archéologie, París, 2002, 257-301, espec. pp. 279-282. 26 Cartulaire de Saint-Sernin de Toulouse. I. Introduction et Index, P. Gérard y T. Gérard (eds.), Amis des Archives de l'Haute Garonne, 1994, pp. 68-69; II, 1, Actes n. ${ }^{\circ} 1-215,1999$, doc. n. ${ }^{\circ} 465$ (1100-1101), pp. 1267-1269.

27 Cazes, Saint-Sernin, pp. 48-49. 
transepto como en la Porte Miègeville, ya señalados en su día por Moralejo ${ }^{28}$, como a la precocidad y madurez que muestran algunos de los capiteles del Claustro de la Catedral de Jaca —en concreto el conservado en la iglesia de Santo Domingo de Jaca (ca. 1105) (fig. 12) 29 — en el conocimiento del taller de la Porte Miègeville (fig. 13). Ello certificaría la presencia y participación de algunos escultores de Jaca en Toulouse entre finales del siglo XI e inicios del XII. De esta experiencia habría salido, en primera instancia, tal y como he defendido recientemente, el célebre Maestro de la Porta Francigena, autor del célebre David de Platerías (fig. 14), que podría haberse incorporado al cortejo de vuelta de Gelmírez en 1100 o ser llamado a Compostela en 1101 tras la consagración del obispo en Compostela. Muy posiblemente, un segundo maestro, el autor del capitel de Santo Domingo de Jaca, habría gozado en esos mismos años de una experiencia similar desde Jaca a Toulouse pero sin pasar por Compostela.

Otro indicio confirmaría este primer itinerario languedociano de Gelmírez. En

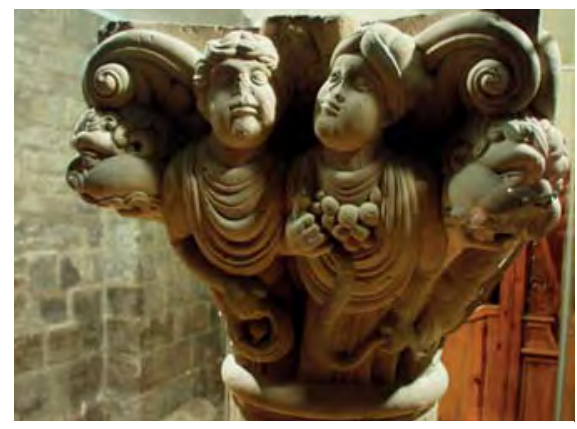

Fig. 12. Iglesia de Santiago y Santo Domingo, Jaca, capitel proveniente del claustro de la Catedral de Jaca, ca. 1105: Saturno y DianaLuna (?).

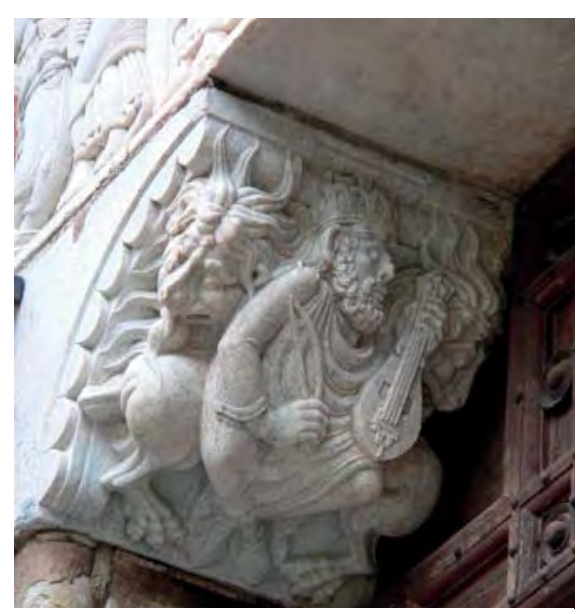

Fig. 13. Catedral de Santiago, fachada sur (Platerías), contrafuerte izquierdo: Maestro de la Porta Francigena, David, 1101-1111. Relieve procedente de la Porta Francigena.

28 S. Moralejo, «Une sculpture de Bernard Guilduin à Jaca», Bulletin Monumental, 131, 1, 1973, pp. 7-16. 29 He tratado la cuestión de la datación alta de los capiteles del Claustro de la Catedral de Jaca y, en concreto, la del de Santo Domingo en relación con la Porte Miègeville en: «Verso Santiago?: la scultura romanica da Jaca a Compostella», en A. C. Quintavalle (dir.), Medievo: l'Europa delle Cattedrali, Atti del IX Convegno Internazionale di Studi, Parma, 19-23 settembre 2006, Electa-Università degli Studi di Parma, Milán-Parma, 2007, pp. 287-296; «Tra Jaca e Compostella: I cantieri Lungo il Cammino di Santiago (1075-1112)», en A. C. Quintavalle (ed.), La Riforma e l'immagine dei cantieri in Occidente, Milán, 2013 (en prensa). 


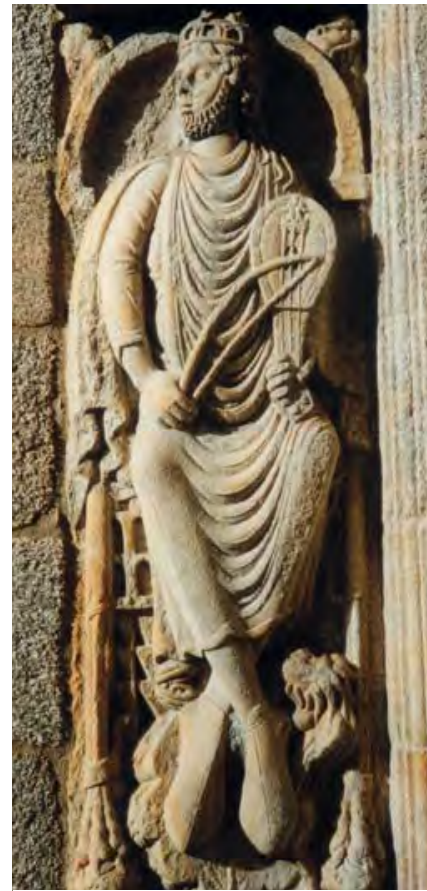

Fig. 14. Saint-Sernin de Toulouse, Porte Miègeville, mocheta derecha: David, ca. 1100-1105.

la Historia Compostelana (I, 9, 2-4) ${ }^{30}$ se nos dice que en 1101, Pascual II, ante la inseguridad del camino a Roma, exime a Gelmírez de tener que ir a la Ciudad Eterna para ser consagrado como obispo. Para ello ordena a Godofredo, obispo de Maguelone, dirigirse a Compostela para dar, en nombre del Papa, su bendición al nuevo prelado. La Catedral de Maguelone, muy cercana a la actual ciudad de Montpellier, se encuentra en una isla que había sido donada desde 1085 a la Iglesia romana y que, por lo tanto, funcionó como refugio de los Papas durante la querella de las investiduras. Es precisamente durante el gobierno del obispo Godofredo (1080-1104) cuando la sede se adhiere de forma tan estrecha al Papado, de manera que allí se instala un cabildo bajo la Regla de San Agustín en 1095, que el propio Papa Urbano II confirma en su visita a Maguelone en $1096^{31}$. Parecería, pues, muy plausible que Gelmírez hubiese visitado, siguiendo la via tolosana — de Montpellier a Arles—, al sabio y reformista obispo Godofredo de Maguelone, quien un año más tarde, como hombre de confianza del Papa, lo consagraría. Sea o no sea verdad, la visita al lugar de Maguelone, una isla inexpugnable en medio de una laguna, le recordaría a Gelmírez la localización del castillo de Catoira, en Galicia, donde su padre había ejercido como tenente.

En el itinerario a través de la via tolosana, el joven Gelmírez había podido seguir por tierra el camino hasta conectar en Luni (Liguria), con la via francigena italiana, o bien desviarse hasta el puerto de Marsella para llegar en barco a Génova o al puerto de Pisa, desde donde alcanzaría la francigena en Lucca. Dos hechos parecen corroborar este último tramo tolosano combinado con un

30 HC, I, 9, 2-4, trad. cit., pp. 87-88.

31 J. Rouette, Histoire du diocèse de Maguelone, Nîmes, 1996 (1921), pp. 94-101. 
embarque marítimo ${ }^{32}$. En primer lugar, el buen conocimiento que el Libro v, 9 del Códice Calixtino tiene de la ciudades de Saint-Gilles y Arles, cuyas reliquias, relicarios —en especial, el Arca de San Gil-y lugares santos son descritos en la Guía de forma minuciosa ${ }^{33}$. En segundo lugar, la existencia de itinerarios similares realizados desde la Península en el siglo xiI, como el emprendido por el rabino Benjamín de Tudela hacia 1160, que, tras recorrer el camino de Saint-Gilles, realiza en barco el trayecto entre Marsella y Génova, para después continuar hasta Pisa y Lucca ${ }^{34}$. Estas dos ciudades italianas están, de hecho, muy ligadas a la política militar y eclesiástica de Gelmírez. Así, de Pisa procedía un tal Frixón, instruido en el arte de navegar, que se hizo cargo de la marina compostelana establecida en Padrón y los puertos de Arousa ${ }^{35}$, mientras que en Lucca residía entonces el archidiácono Gregorio, futuro cardenal de San Crisógono de Roma (1109-1111) y autor del Polycarpus, libro de cánones dedicado a Diego Gelmírez hacia 1109, en cuyo proemio se deduce que ambos se habían conocido anteriormente: "petistis jam dudum et hoc saepe [...] librum canonum» (Vat. Lat. 1354, f. 1r) ${ }^{36}$.

Aunque no sabemos exactamente las etapas que siguió la comitiva, es muy posible que el intrépido Gelmírez hubiese viajado entonces en el más estricto

32 Los argumentos para la reconstrucción de este viaje han sido expuestos anteriormente por mí en: "Platerías: función y decoración de un "lugar sagrado"», en Santiago de Compostela: ciudad y peregrino, Actas del V Congreso Internacional de Estudios Jacobeos, Xunta de Galicia, Santiago, 2000, pp. 289-331, espec. 294-295; «El porqué de una exposición itinerante. Diego Gelmírez, genio y espíritu viajero del Románico", en M. Castiñeiras (ed.), Compostela y Europa. La historia de Diego Gelmírez, Milán, 2010, pp. 16-29, espec. pp. 20-21 (mapa). Adeline Rucquoi prefiere, en cambio, para este viaje de 1100, una poco probable y peligrosa ruta marítima directa desde Barcelona a Italia ("Diego Gelmírez: Un archevêque de Compostelle pro-français», Ad Limina, 2, 2011, pp. 157-176, espec. p. 168).

$33 \mathrm{cc}, \mathrm{v}, 8$, trad. cit, pp. 525-531.

34 Libro de viajes de Benjamin de Tudela, introd., trad. y notas de J. R. Magdalena Nom de Déu, Barcelona, 1989, pp. 58-59.

35 «Pues mandó construir con gran gasto una birreme, que se llama vulgarmente "galera", y una vez construida la entregó a un joven llamado Frixón, oriundo de la ciudad de Pisa, de buenas costumbres y muy experto en artes náuticas, para que navegando con ella se dirigiera contra la tierra de los amorreos», HC, II, 85, trad. cit., pp. 449-450; Filgueira Valverde, «Gelmírez, constructor», pp. 71-72. La Compostelana fecha el acontecimiento tras la consecución del arzobispado por Gelmírez (HC, II, 85, trad. cit., p. 449), es decir, después de 1120 .

36 U. Horst, Die Kanonensammlung Polycarpus von Gregor von S. Crisogono. Quellen und Tendenzen, Monumenta Germaniae Historica, Hilfsmittel, 5, Munich, 1980, pp. 3-4; Castiñeiras, «Platerías: función y decoración», pp. 294-295; V. Nodar, «Polycarpus», Compostela y Europa, ficha cat. n. ${ }^{\circ} 22$, pp. 354-355. 
anonimato por miedo a ser capturado o reconocido por el depuesto obispo de Compostela, Diego Peláez (1075-1088), que vivía exiliado en la Corte de Pedro I de Aragón y Navarra (1094-1104) y que todavía albergaba deseos de volver. De ahí las reticencias, meses después, de la curia compostelana a que Gelmírez repitiese en 1101 ese viaje por tierras de Aragón para ser consagrado obispo en Roma (HC, I, 9, 1) ${ }^{37}$. Considero, pues, poco probables otras posibilidades, como la de que Gelmírez hubiese evitado en 1100 el reino de Aragón a través del Reino Taifa de Zaragoza para alcanzar el condado de Barcelona y desde allí embarcar rumbo al puerto pisano. Cabe recordar que entonces la seguridad de la navegación en esa franja central del Mediterráneo Occidental estaba amenazada por los constantes ataques de los piratas sarracenos de Mallorca. Habrá, pues, que esperar a la expedición catalano-pisana de 1114-1115, con la conquista de Mallorca, para asegurar un tránsito fluido por dichas aguas ${ }^{38}$.

Una vez vuelto de Roma como subdiácono en 1100, Gelmírez tuvo que esperar hasta la Pascua del ańo siguiente, el 21 de abril de 1101, para ser consagrado obispo en Compostela. Según Gordon Biggs, muy probablemente Diego tuvo que ser ordenado, a toda prisa, diácono y presbítero en los días anteriores, quizás el 6 y el 20 de abril ${ }^{39}$. Unos años después, en 1105, fallecidos Pedro I y probablemente Diego Peláez — cuya última mención documental se fecha en Leyre en 1104_- Gelmírez emprende un segundo viaje — bien detallado en la Historia Compostelana - en el que no duda en atravesar las montañas vasco-navarras (HC, I, 16, 1 ${ }^{40}$. Muy posiblemente la elección del tramo navarro para llegar a Ostabat, pasando por Pamplona y Roncesvalles, para después alcanzar la via Tolosana, se explica en el marco de las buenas relaciones existentes entre el nuevo prelado compostelano y Pedro de Rodez, obispo de Pamplona, quien en 1101 había contratado para su fábrica a Esteban, maestro de obras de Santiago, y que a la vuelta del periplo gelmiriano le pidió a éste consagrar la capilla de Santa Fe en la cabecera de la catedral compostelana (HC, I, 19) ${ }^{41}$.

37 HC, I, 9, 1, trad. cit., p. 86.

38 Sobre la breve conquista de Mallorca en 1114-1115, véase J. E. Ruiz Domenéc, Ricard Guillem o el somni de Barcelona, Barcelona, 2001, pp. 151-158.

39 G. Biggs, Diego Xelmírez, Vigo, 1983, pp. 51 y 298, nota 211 (1a ed. ing. 1949).

$40 \mathrm{HC}, \mathrm{I}, 16,1$, trad. cit., p. 100.

41 HC, I, 19, trad. cit., p. 109. 
El itinerario del viaje de 1105 sorprende porque fue aprovechado para adentrarse en tierras galas, camino de Cluny (fig. 16). Gelmírez siguió primero la via tolosana, visitando Auch y Toulouse, para luego tomar la via podiensis, con parada en Moissac y Cahors. En mi opinión, aunque no queda recogido en la Compostelana, la comitiva se habría acercado también a la abadía de Conques, dada la estrecha relación que unía a Santiago con el santuario de Santa Fe desde los inicios de la Catedral. Seguidamente, tras desviarse por Uzerche, hacia la via lemosina, en ella Gelmírez hace parada en Limoges, St. Léonard de Noblat, Sainte Valerie, y, finalmente, llega a Cluny, donde es recibido por el todopoderoso abad Hugo, celebrando una misa la festividad de San Miguel (29 de septiembre) de $1105^{42}$. Desde allí alcanzó los valles de Moriana y, en la ciudad de Susa, baja por la via francigena italiana hasta Roma, disfrazado de soldado ${ }^{43}$, pasando probablemente por Pavía, Piacenza, Fidenza, Luni, Lucca, Altopascio, Siena, S. Quirico d'Orcia, Viterbo y Sutri. Para la reconstrucción hipotética de este itinerario a través de la francigena, contamos con el precedente de Sigeric, arzobispo de Canterbury, que, tras recibir el palio en Roma, volvió a su sede por ese mismo camino hasta Pavía, o con la peregrinación del abad islandés Nikulas de Munkathvera (1151-1154) o la del rey Felipe II Augusto a su retorno de la Tercera Cruzada en $1191^{44}$. No puede descartarse, sin embargo, que la comitiva compostelana haya tomado, en la ida o en la vuelta, el trazado de la via Aemilia, de Piacenza a Forlí, pasando por Parma, Módena y Bologna, para luego bajar por Bagno di Romagna, Arezzo, Perugia, Spoleto, Foligno, Rieti y Roma, tal y como hizo el monje de St. Albans - Matthew Paris - en la primera mitad del siglo XIII ${ }^{45}$.

Finalmente, el 31 de octubre de 1105, en la basílica romana de San Lorenzo Extramuros, Gelmírez recibió el palio de manos del Papa Pascual II $(1099-1118)^{46}$. Aunque tradicionalmente el privilegio se venía fechando en las

\footnotetext{
42 Hс, I, 16. 2 (Auch), 3 (Toulouse-Moissac-Cahors), 4 (Uzerche-Limoges-Sainte Valerie), 5-6v (Cluny), trad. cit., pp. 100-101.

43 нс, I, 17, 1 (Moriana-Susa-Roma), trad. cit., pp. 103-104.

44R. Stopani, La Via Francigena. Una strada nell'talia del Medioevo, Florencia, 1988, pp. 16-25, 53-70;

B. Birch, Pilgrimage to Rome in the Middle Ages. Continuity and Change, Woodbridge, Suffolk, 1998, pp. 10-11.

45 Cfr. Stopani, La Via Francigena, pp. 98-99; Birch, Pilgrimage to Rome, pp. 9, 44, 47-48.

46 HC, I, 17, 2, trad. cit., pp. 104-105.
} 
ediciones de la Historia Compostelana como de 1104, Ludwig Vones, a partir del análisis de la copia del documento en el Tumbo B del Archivo de la Catedral de Santiago (fols. 225v-226r), estableció definitivamente que el viaje y el hecho tuvieron lugar en $1105^{47}$.

Desde un punto de vista artístico, resulta obvio el impacto y las consecuencias de los itinerarios gelmiríanos de 1100 y 1105 . En ambas ocasiones, la comitiva compostelana tuvo la oportunidad de conocer, de primera mano, los grandes centros creadores del arte románico del momento, como los obradores abiertos de Jaca, Toulouse, Conques y Cluny, u obras recién concluidas como el Claustro de San Pedro de Moissac. No hay que olvidar que muchas de las peculiaridades tipológicas (puerta bífora con relieves), temáticas (Apostolados, Teofanías, repertorio profano) y programáticas (exaltación de la vita apostolica, condena de los vicios) de las fachadas compostelanas derivan de los citados monumentos galos. Del mismo modo, en su periplo italiano, Gelmírez y sus acompańantes pudieron contemplar el resurgimiento del arte monumental promovido por la ideología de la Reforma Gregoriana, que recurriendo a los modelos paleocristianos quería retornar a los orígenes de la Iglesia y enseñar, además, los dogmas de la fe a través de las imágenes en una especie de «escritura para iletrados». De hecho, la amplitud del programa de la Porta Francigena, con temas como los meses, el repertorio profano y la historia del Génesis, y su claro abuso en la utilización del friso historiado y figuras de jamba, enlazan con las preocupaciones de las fachadas de Wiligelmo en Módena (Puerta Occidental y Porta della Pescheria) y en Cremona.

No obstante, lo que subyace tras estos viajes es la firme adhesión compostelana al modelo estético-ideológico de una Roma papal, paleocristiana y antigua. Con ello, Gelmírez supera las viejas reticencias de los pontífices a la sede jacobea, que se habían concretado en la excomunión del obispo Cresconio por León Ix en el Concilio de Reims de $1049^{48}$. La condena tenía que ver con la costumbre de los obispos de Iria-Santiago de arrogarse el título de «obispo de la sede apostólica».

47 L. Vones, Die Historia Compostellana und die Kirchenpolitik des Nordwestspanischen Raumes 1070-1130, Colonia, 1980, pp. 160-161, notas 60 y 60a. Consúltese una correcta edición del documento en Tumbo $B$ de la Catedral de Santiago, M. T. González Balasch (ed.), Santiago, 2004, pp. 525-527.

48 A. Isla Frez, Memoria, culto y monarquía hispánica entre los siglos X y XII, Universidad de Jaén, 2006, pp. 97-98 
Ahora bien, con el reformista Gelmírez, una vez eliminado su opositor Diego Peláez, el nuevo camino de la futura sede metropolitana parecía ir de la mano de Roma. Quizás estos fueron los pensamientos del joven Gelmírez, cuando en 1100 se postró delante de la confessio de San Pedro del Vaticano, ante la doble fila de columnas salomónicas de la pérgola, para recibir, según el ritual canónico, el subdiaconado ${ }^{49}$. Esas mismas reflexiones lo asaltarían en el momento de recibir el palio en la antigua basílica cementerial de San Lorenzo Extramuros, en medio de sarcófagos antiguos y paleocristianos. Las consecuencias artísticas que ambos momentos simbólicos tuvieron sobre la obra compostelana fueron, en primera instancia, señaladas por S. Moralejo ${ }^{50}$, tanto en las columnas entorchadas procedentes de la Porta Francigena, como en la sistematización de una frontal y un baldaquino de plata en el altar mayor (fig. 3). Sus conclusiones, no obstante, fueron reformuladas por mí, con nuevas aportaciones, en el ańo 2002, al proponer una inspiración directa del Maestro de las Columnas Entorchadas en las obras de marmolistas romanos coetáneos, del Maestro de la Porta Francigena en el repertorio dionisíaco del sarcófago tardoantiguo reutilizado como tumba del Papa Dámaso II (+ 1048) en San Lorenzo Extramuros así como al señalar todo lo que de emulación de las basílicas romanas tiene la creación de una confessio bajo la parte trasera del altar de Santiago ${ }^{51}$. A ello hay que ańadir la cita paleocristiana y lateranense del friso de la Pasión de Cristo del Maestro de Conques (o de las Tentaciones) en Platerías $^{52}$. Ello es visible tanto en el uso de composiciones - la Curación del Ciego o la Coronación de Espinas - y temas - Pasión sin crucifixión- derivados de sarcófagos paleocristianos como en la minuciosa representación de la columna de la Flagelación (fig. 15). Su altura, sin el plinto que la eleva, es igual a la de la figura de Jesús, en un intento por reproducir o evocar la célebre columna con la mensura Christi, visible en la Roma medieval en la antigua Sala del Concilio del Palacio de Letrán y actualmente conservada en el Claustro de la basílica lateranense (fig. 16).

\footnotetext{
49 Para una descripción de la pérgola de San Pedro de Roma y el rito de las ordenaciones, véase: S. de Blaauw, Cultus and decor. Liturgia e architettura nella Roma tardoantica e medievale, Ciudad del Vaticano, 1994, pp. 553-554, 604.

50 Moralejo, «El patronazgo artístico de Diego Gelmírez».

$51 \mathrm{M}$. Castińeiras, «Roma e il programma riformatore».

52 M. Castińeiras, "Didacus Gelmirius»; «Las portadas del crucero de la Catedral de Santiago (1101-1111)», en C. Estepa, E. Fernández, J. Rivera (dirs.) Alfonso VI y su legado, Actas del Congreso Internacional celebrado en Sahagún, León, 2012, pp. 215-241, espec. pp. 234-235, figs. 32-35.
} 


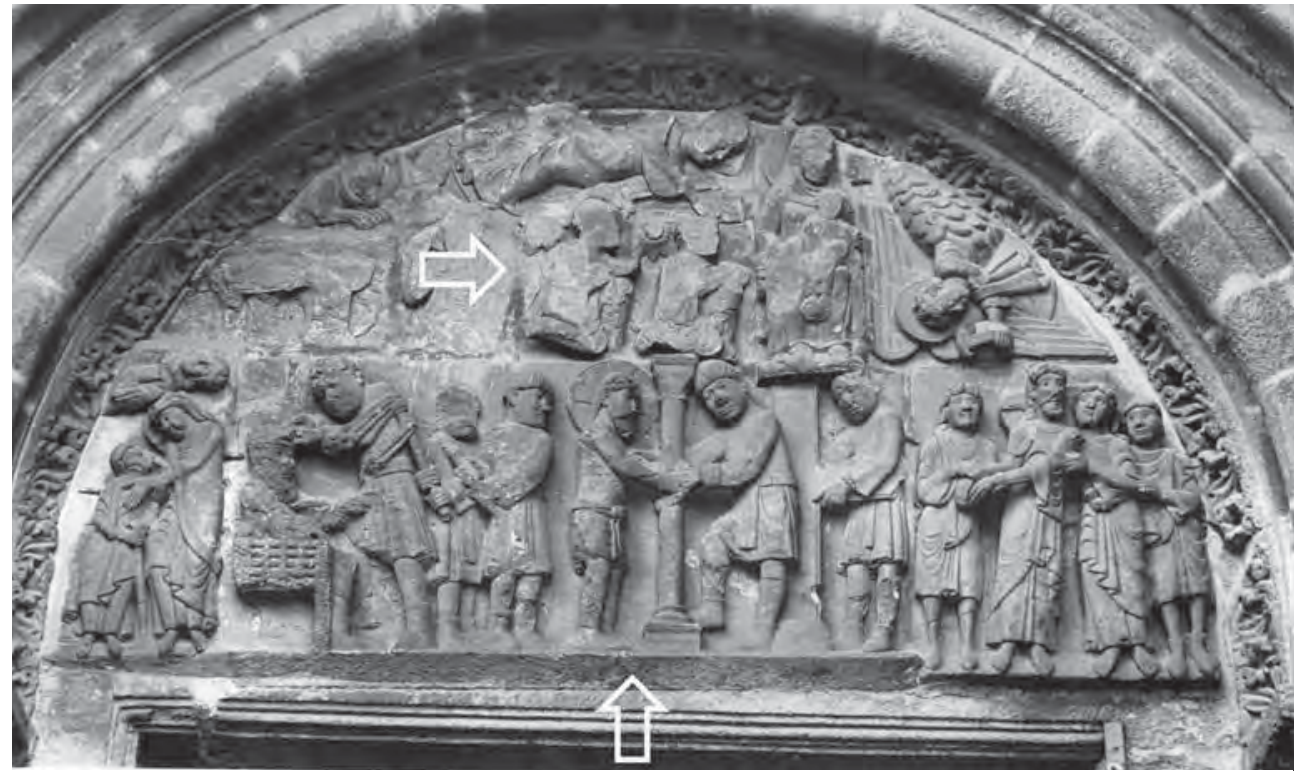

Fig. 15. Catedral de Santiago, fachada sur, ingreso derecho: las flechas señalan las lastras de la Vida de Cristo atribuidas al Maestro de Conques o de las Tentaciones, 1101-1103.

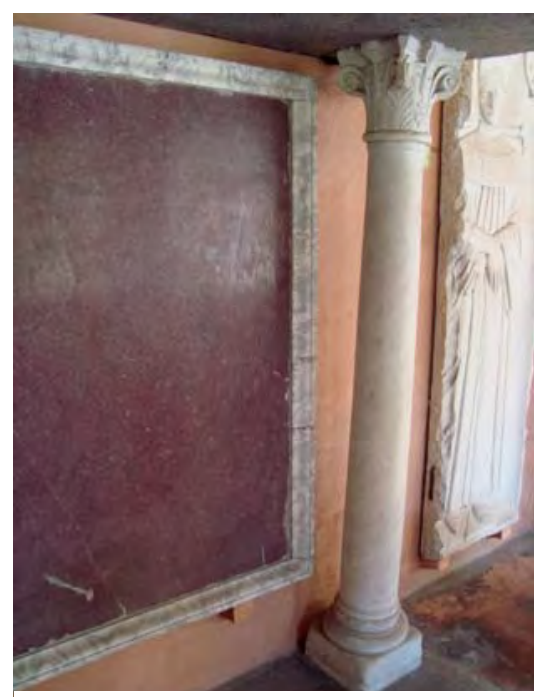

Fig. 16. Roma, San Juan de Letrán, claustro: una de las columnas con la mensura domini procedentes del Aula de los Concilios.
No cabe, pues, duda alguna de que las portadas del transepto compostelano y la nueva sistematización del altar mayor jacobeo son productos directos de los viajes de Gelmírez por tierras galas e italianas. Solo a partir de 1100-1101 puede hablarse de un verdadero "arte gelmiriano», cuya época dorada finaliza en torno a 1122-1124. Entre esas dos fechas, Compostela pudo desarrollar un programa figurativo perfectamente vanguardista, que sintetizaba la experiencia del arte de los Caminos de Peregrinación con la emergencia del arte de la Reforma Gregoriana en Italia. Sus hitos son los siguientes: elevación de las fachadas del transepto entre 1101 y 1111, y consagra- 
ción del altar mayor y capillas de la cabecera, entre 1105 y 1106 . Unas serie de fechas parecen corroborarlo: el inicio del nuevo palacio en la platea de Platerías en 1101; la inscripción de la jamba izquierda de la entrada oriental de Platerías, realizada en 1103; la inscripción conmemorativa de la consagración de la Capilla del Salvador y el epígrafe del frontal de plata, colocado en el quinto año del pontificado de Gelmírez; el enterramiento del Conde de Galicia, Ramimundo de Borgońa, en la Porta Francigena en 1107; la inscripción laudatoria al rey de Galicia, Alfonso Raimúndez, en el friso de Platerías, con motivo de su coronación en el altar mayor jacobeo en 1111; y la definitiva destrucción del perímetro de la basílica de Alfonso in en 1112. Por el contrario, la fecha de 1122 de la fuente del Paradisus señalaba la finalización de tribunas, cubiertas y espacios públicos en el entorno de la cabecera y transepto de la catedral.

\section{UN TALLER INTERNACIONAL PARA LAS FACHADAS COMPOSTELANAS}

La realización de la Porta Francigena y de Platerías necesitaba de la participación de artesanos hábiles en el manejo del cincel, que, a mi entender, fueron contratados durante el primer viaje de Gelmírez o como directa consecuencia del mismo. Hacia 1101, un año después del primer itinerario a Roma, tras la consagración episcopal del 21 de abril de 1101 y el consiguiente inicio de las obras del nuevo palacio episcopal en la platea sur, tuvieron que iniciar sus trabajos los cinco maestros activos en las portadas: el Maestro de la Porta Francigena, el Maestro de las Columnas Entorchadas, el Maestro del Cordero, el Maestro de las Tentaciones (o de Conques) y el Maestro de la Traición. Mientras que cuatro se dedican fundamentalmente a la portada norte _-Francigena, Entorchadas, Cordero y Traición-, el de las Tentaciones se consagra exclusivamente desde el primer momento a la puerta sur. Sin embargo, un cambio de proyecto en Platerías hace que, alrededor de 1103, el maestro de la Porta Francigena y el de la Traición incorporen sus relieves a dicha fachada sur. En mi opinión, hacia 1105, los Maestros de las Tentaciones y de la Traición aprovecharon el segundo viaje de Gelmírez para volver a Conques e incorporarse de nuevo al taller del abad Bégon III, de donde habían salido ańos antes camino 
de Compostela ${ }^{53}$. En Platerías trabajaría también un sexto maestro, el Maestro de la Transfiguración, que no trataremos aquí.

Como ya se ha señalado, el presente trabajo se centrará en el análisis de los maestros activos en la Porta Francigena ${ }^{54}$. El primero y más genial, que denominamos propiamente el Maestro de la Porta Francigena, fue el que en su día Moralejo llamó «de Platerías» y al que la vieja historiografía quiso identificar, de forma totalmente errónea, con el Maestro Esteban. Su nuevo nombre hace así justicia a la obra para la que esculpió sus más célebres relieves — la Porta Francigena—, en la que seguramente actúo como maestro principal, imponiéndole a la misma un aspecto «antiquizante» en la disposición en friso de las lastras de su frontispicio. Dicho escultor es, sin duda alguna, con sus peculiares figuras de rostros de carrillos hinchados, vigorosa anatomía y contrastado modelado de paños (Creación de Adán, David [fig. 14], Mujer del León, Mujer de las Uvas, Hombre que cabalga el gallo, etc.), un heredero del gusto por la Antigüedad del Maestro de Jaca que debió conocer directamente - o incluso formarse - en la extraordinaria experiencia monumental del taller de la Porte Miègeville de Saint-Sernin de Toulouse, en cuyos relieves ya se trabajaba posiblemente hacia 1100 (fig. 13), tal y como sugieren las investigaciones de Daniel y Quitterie Cazes ${ }^{55}$. Muy posiblemente es gracias al viaje que Gelmírez realiza a Roma en 1100, acompañado por miembros de su curia, para ser ordenado subdiácono, a través de la via tolosana, que dicho maestro foráneo se incorporó al nuevo obrador compostelano. Más allá de las coincidencias iconográficas y paralelismos estilísticos que todos los autores han señalado entre los relieves de este maestro y el taller de la Porte Miègeville (David sonando la fídula de arco, relieve con Signum Leonis y Signum Arietis), habría que añadir otras pistas. Me refiero, en concreto, a la imagen del Ballestero (fig. 17), actualmente reutilizada en Platerías pero procedente del friso inferior de la Porta Francigena. La pieza, que debe atribuirse al Maestro de la Porta Francigena, toma como modelo una imagen que se encuentra en un capitel del claustro de Moissac (1085-1100) (fig. 18). El autor seguramente accedió al repertorio de dicho priorato cluniacense en Toulouse, mientras se formaba en el taller de la Porte Miègevi-

53 M. Castiñeiras, «Da Conques a Compostella».

54 En la definición de todos estos «maestros» se parte de trabajos de Moralejo de 1969 («La primitva puerta norte»), incorporando aportaciones y matices importantes desarrollados en los últimos años.

55 D. y Q. Cazes, Saint-Sernin de Toulouse. 
lle, pues en este se conocían a la perfección las obras recién finalizadas de Moissac; lugar, que tan solo unos años más tarde, en 1105, visitará el propio Gelmírez.

El segundo maestro, responsable de las magníficas columnas entorchadas (fig. 19) - Maestro de las Columnas Entorchadas, al que F. Prado-Villar denomina Maestro de Uli$\operatorname{ses}^{56}$ - , estaba formado igualmente en la tradición jaquesa, pero se caracteriza por permanecer más fiel al clasicismo que caracterizaba a este taller y enriquecerlo con las novedades de la experiencia romana contemporánea, como veremos más adelante. A ellos hay que añadir el denominado Maestro de la Puerta del Cor-

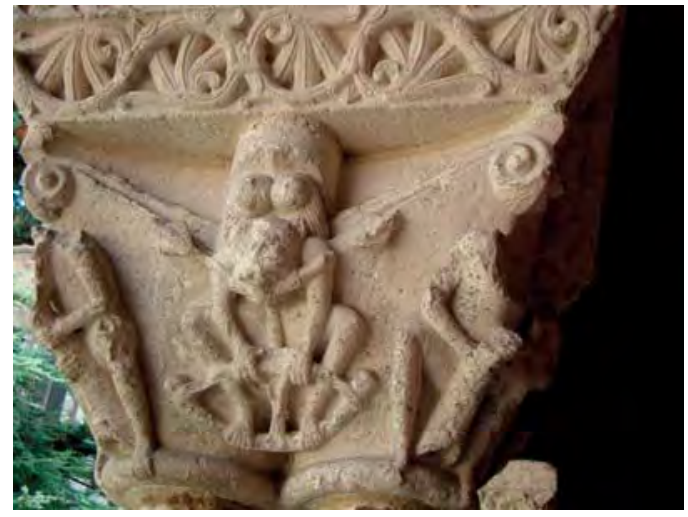

Fig. 18. Saint-Pierre de Moissac, claustro, galería oeste, capitel con el Ballestero, 1085-1110.

Fig. 19. Maestro de las Columnas Entorchadas: fragmento de fuste entorchado procedente de la primitiva Porta Francigena: 1101-1111. Museo da Catedral de Santiago.

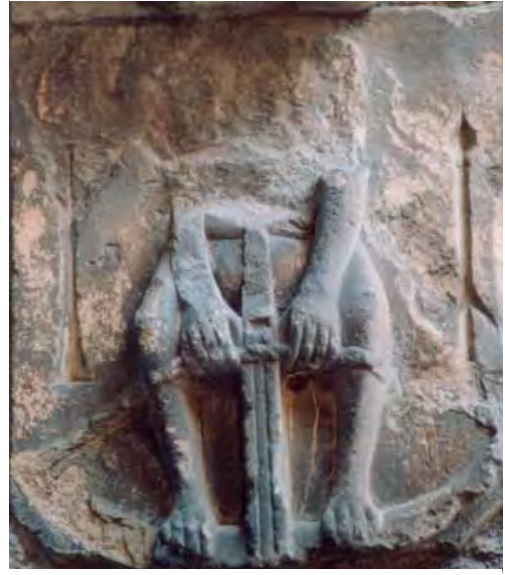

Fig. 17. Catedral de Santiago, fachada sur (Platerías), puerta izquierda, jamba derecha: Maestro de la Porta Francigena, el Ballestero, 1101-1111. Relieve procedente de la Porta Francigena.

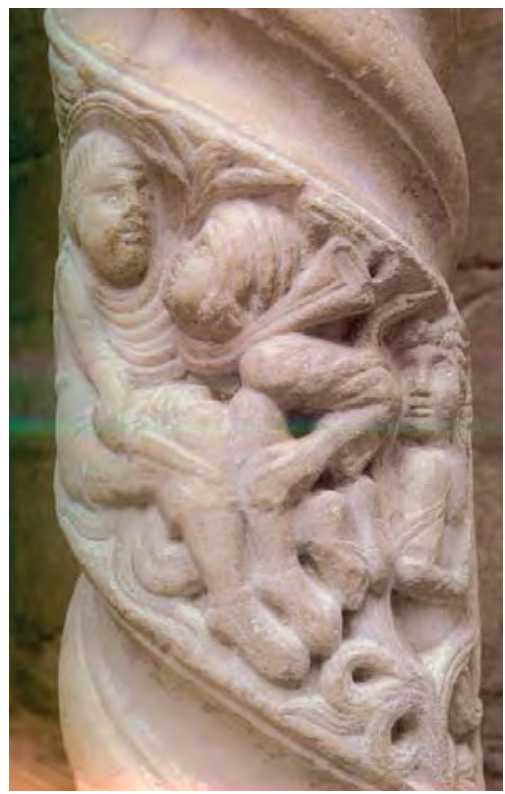

56F. Prado-Villar, «Nostos, Ulises, Compostela y la ineluctable modalidad de lo visible», en M. Castińeiras (ed.), Compostela y Europa. La historia de Diego Gelmirez, Milán, 2010, pp. 260-269. 
dero, de volúmenes geométricos, de superficie pulimentada, rostros intemporales, ojos abultados y tendencia a la frontalidad (Pantocrátor del contrafuerte izquierdo de Platerías, Signo de Mateo, Creación de Eva). Se trata de un escultor local, activo en León, conocedor de la tradición jaquesa y las aportaciones del Maestro de la Porta Francigena, pero menos dotado para articular un lenguaje artístico monumental sofisticado. Por último, en la Porta Francigena trabaja también un cuarto artista, de formación muy distinta a los tres precedentes: el Maestro de la Traición. Se trata de un seguidor del Maestro de las Tentaciones, y como él procedente del Conques del abad Bégon, que domina la narración y utiliza figuras en tres cuartos, de rostros ingenuos, pupilas excavadas rellenas de pasta vítrea, grandes bigotes, pliegues gruesos que se ciñen a la parte inferior del cuerpo y marcada tendencia al bulto (Reprensión y Expulsión de Adán y Eva).

De manera extraordinaria para esas fechas, los relieves salidos de la mano de los diferentes escultores cubrieron, como en la fachada sur —Platerías_-, la totalidad de la superficie de la fachada norte. Su primitiva ubicación en la misma se conoce gracias a la descripción de la Guía del Calixtino (v, 9): jambas con Apóstoles, mochetas con cabezas de buey, enjutas extremas con leones, tímpano del ingreso izquierdo con la Anunciación, así como un frontispicio profusamente decorado. En él se incluían, directamente sobre los arcos de las puertas, sendos frisos de pequeńas lastras con relieves profanos consistentes en un ciclo con los Meses del Año —izquierda - y personificaciones del pecado, compuestas por el Centauro, la Sirena, el Ballestero (fig. 17) y el Hombre que cabalga un gallo. Estos últimos cuatro relieves, de formato cuadrangular similar, en origen formaban parte de la serie de las imágenes de «bestias, de hombres, de ángeles, de mujeres, de flores y de otras criaturas» (Guía del Calixtino v, 9) que decoraban el primitivo portal y que fueron en el siglo Xvin reaprovechados en Platerías. Aunque desconocemos exactamente la localización exacta de estos últimos relieves dentro de la fachada primitiva, algunos indicios y el posible eco de su estructura en la fachada norte de San Quirce de Burgos ${ }^{57}$ llevan a pensar en su colocación en friso sobre la

57M. Castiñeiras, «Didacus Gelmirius», pp. 65-67. Sobre el conjunto de San Quirce de Burgos, véase el sugerente estudio de D. Rico Camps, Las voces del Románico. Arte y epigrafía en San Quirce de Burgos, Murcia, 2008, especialmente p. 89. 
puerta derecha en perfecta simetría con el de los Meses situado sobre la puerta izquierda.

Otro monumento sugerente, respecto a la Porta Francigena, es la Puerta del Cordero de San Isidoro de León, cuyo frontispicio, sin embargo, fue alterado en época moderna para colocar la actual peineta que lo corona (fig. 20). De hecho, el célebre friso del Zodiaco estaba acompañado, probablemente

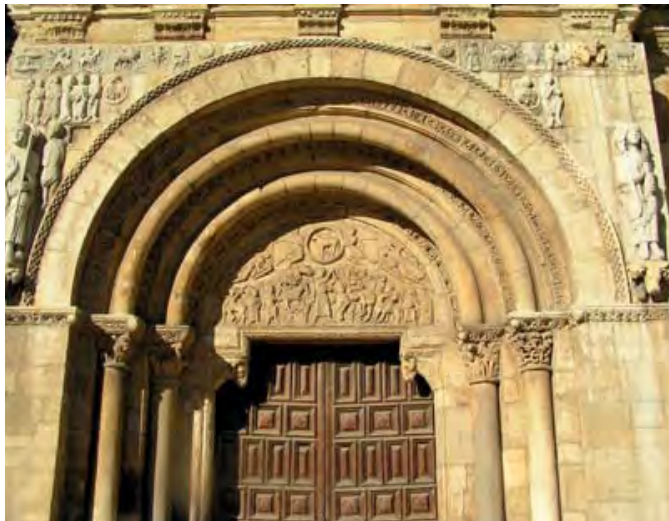

Fig. 20. San Isidoro de León, lado sur, Puerta del Cordero, ca. 1101. en la parte superior, de una serie de tituli que corroboran su lectura de derecha a izquierda: «GEMINI: TAU/RUS: $\mathrm{ARIES}_{{ }^{58}}{ }^{8}$. Aunque hace años propuse que signos e inscripciones conformaban, en origen, un friso de canes y metopas, un análisis detenido de las piezas me hace descartar esa posibilidad: los signos zodiacales, en su actual disposición, presentan una anchura irregular, más estrechos en la parte central —Cáncer y Virgo-, que sugieren su concepción primigenia como friso corrido sobre una puerta, tal cual todavía están hoy. Su similitud con el destruido calendario de la Francigena resulta obvia, si bien en Compostela se invierten los términos respecto a León: en el primero, el friso de los Meses se sitúa entre el gran despliegue narrativo del Génesis y la arquivolta izquierda, mientras que en el segundo, el friso zodiacal corona la fachada sobre la representación de David y sus músicos. Para valorar los intercambios entre ambos conjuntos habría primero que resolver la cuestión de la datación controvertida de la Puerta del Cordero. Para Therese Martin, Marta Poza y Francisco Prado-Villar ${ }^{59}$ se trataría, utilizando distintos argumentos, de un

58 Sobre la localización actual de estos epígrafes, véase: T. Martin, Queen as King. Politics and Architectural Propaganda in Twelfth-Century Spain, Brill, Leiden-Boston, 2006, p. 92, fig. 39ab. Para un estudio de la iconografía del zodiaco leonés, véase: S. Moralejo, «Pour l'interprétation iconographique du Portail de l'Agneau à Saint-Isidore de León: les signes du zodiaque», Les Cahiers de Saint-Michel de Cuxa, 8, 1977, pp. 137-173.

59T. Martin, Queen as King, 92; M. Poza y Agüe, «Entre la tradición y la reforma. A vueltas de nuevo con las portadas de San Isidoro de León", Anuario del Departamento de Historia y Teoría del Arte, xv, 2003, pp. 9-27; F. Prado-Villar, «Lacrimae rerum: San Isidoro de León y la memoria del padre», Goya, 328, 2009, 
conjunto realizado bajo el mecenazgo de la infanta Urraca de Zamora, patrona de San Isidoro, entre la década de 1090 y el año de su fallecimiento, 1101, mientras que Gerardo Boto, a partir del análisis de las fases constructivas del edificio, propone que la portada estaría realizada antes del año 1110, si bien reconoce que ya se debía estar trabajando en la fachada en $1101^{60}$. En mi opinión, siguiendo, en particular, la sólida hipótesis de Francisco Prado-Villar ${ }^{61}$, existen suficientes argumentos para pensar que en la concepción del citado portal leonés se gestaron algunas de las soluciones de la Francigena, como la tipología de friso sobre puerta o el carácter artístico del denominado "Maestro del Cordero" activo en la Porta Francigena, deudor epigonal del estilo de las lastras mayores de las enjutas del

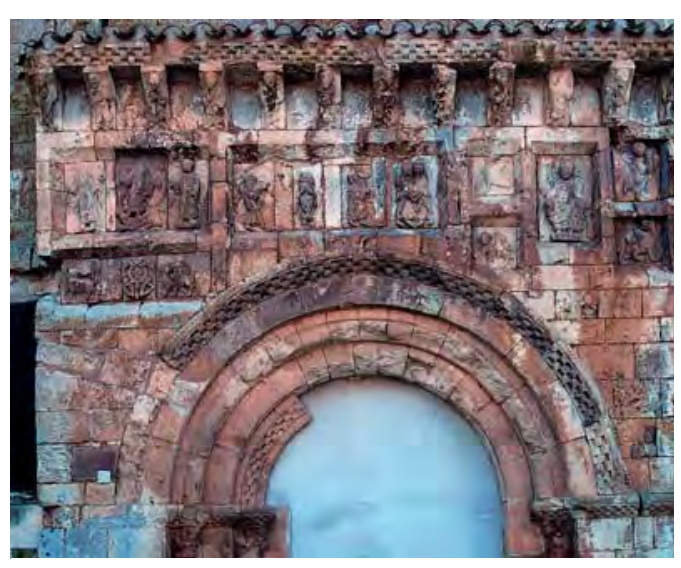

Fig. 21. San Quirce de Burgos, puerta norte, $1125-1150$. citado portal leonés.

Volviendo a lo que la portada norte de San Quirce de Burgos (fig. 21) pudiera tener de eco de las portadas del transepto compostelano, me gustaría llamar la atención sobre una serie de cuestiones. En primer lugar, desde un punto de vista tipológico, la portada burgalesa presenta un frontispicio totalmente cubierto de relieves cuadrangulares y rectangulares, como sucedía en las fachadas compostelanas, y se enmarca con un animado alero de canes figurados, como el que seguramente existía en la primitiva Porta Francigena o el que todavía puede contemplarse en Platerías. Por otra parte, en lo que se refiere a su iconografía, en San Quirce se repiten muchos temas de las portadas compostelanas: así, el Cristo en Majestad rodeado de un Tetramorfos y la Anunciación del frontispicio burgalés se situaban, en la Porta Francigena, respectivamente, en el centro y en uno

pp. 195-221, especialmente p. 218, n. 41 y 43.

60 G. Boto Varela, Arquitectura Medieval. Configuración espacial y aptitudes funcionales, San Isidoro de León. Relicario de la monarquía leonesa, C. Robles y F. Llamazares (eds.), León, 2007, pp. 52-103.

61 F. Prado-Villar, Lacrimae rerum, p. 218, n. 41 y 43. Agradezco a Francisco Prado-Villar sus útiles y atinadas indicaciones sobre la cronología de la Puerta del Cordero. 
de los tímpanos, mientras que el apostolado que decora el alero se encontraba en Platerías en el frontispicio.

Todas las piezas del repertorio profano de la primitiva puerta norte de Santiago - Centauro, la Sirena, el Ballestero y el Hombre que cabalga un gallo- son atribuibles al Maestro de la Porta Francigena y aluden a las consecuencias derivadas del Pecado Original, cuya historia se exponía en el friso superior contiguo. La música de la voz de la Sirena representaba desde La Odisea el encantamiento de la destructora seducción femenina, imagen ahora del engaño y el embrujo de los placeres del mundo. Por ello la figura es herida por las flechas del Centauro, representando así una alegoría de la lucha contra el mal. Por su parte, el Hombre cabalgando un gallo constituía por antonomasia la imagen de la lujuria masculina. De esta forma, las lastras funcionarían como metafóricas referencias a la codicia y lubricidad de Adán y Eva y al poder seductor del demonio. Por último, el Ballestero (fig. 17), imagen de la discordia, amplifica los efectos del Pecado Original, ya que no hay que olvidar que la ballesta no solo era odiada entonces por su potencia mortífera sino que era considerada un arma diabólica, llegando incluso a ser condenado su uso en el II Concilio Lateranense ${ }^{62}$.

El frontispicio estaba presidido, justo sobre ambos ciclos profanos, por un gran friso historiado de temática bíblica compuesto por multitud de piezas que narraban la historia de la Creación y Caída de Adán y Eva, siguiendo los modelos ilustrativos de las biblias carolingias (fig. 8). En el centro de este programa se situaba la figura de Pantocrátor con los cuatro símbolos de los Evangelistas. Muy posiblemente a ambos lados de este gran ciclo bíblico se disponían lastras, igualmente de formato rectangular, relativas a la promesa de redención —David

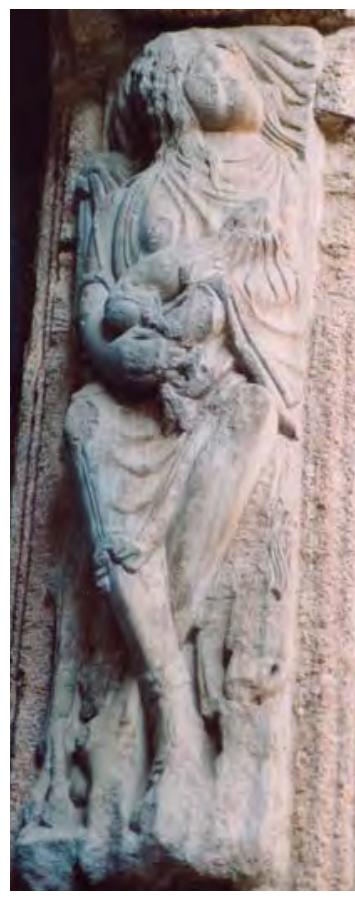

Fig. 22. Maestro de la Porta Francigena, Mujer del León, 1101-1111. Platerías, puerta derecha, jamba derecha.

62 M. Castiñeiras, "A poética das marxes no románico galego: bestiario, fábulas e mundo ó revés», en M. Castińeiras y F. Díez Platas (eds.), Profano y pagano en el arte gallego, Santiago, 2003, pp. 293-334, espec. p. 310 (Semata, 12, 2002). 


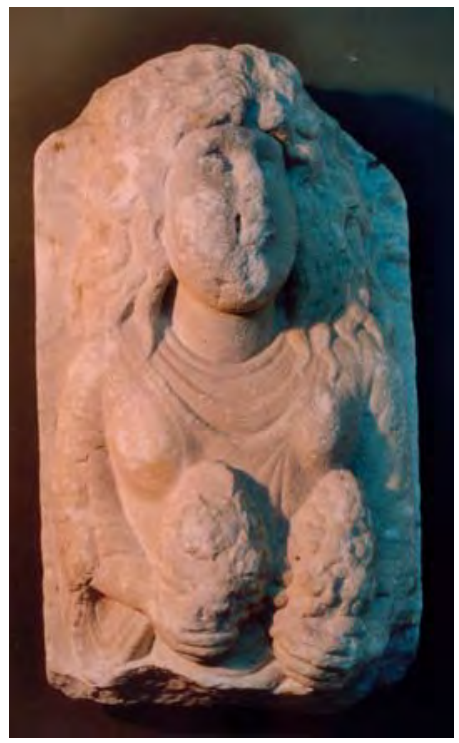

Fig. 23. Maestro de la Porta

Francigena, Mujer de los Racimos de Uvas, 1101-111. Museo da Catedral de Santiago.

músico vence al demonio, Sacrificio de Isaac, Mujer del león, Mujer de las uvas. El misterioso contenido de estas dos immagines feminarum (figs. 22-23), a las que se refiere el Códice Calixtino (V, 9), hay que interpretarlo, tal y como señaló en su día S. Moralejo, en clave cristológica, como imagen alegórica de las dos naturalezas, divina y humana, de Cristo: león vencedor pero también víctima de sacrificio. El Mesías, de hecho, era el cachorro de león de la profecía de Jacob, metáfora de la muerte y resurrección de Cristo: «Cachorro de león es Judá; de la presa, hijo mío, he vuelto; se recuesta, se echa cual león, o cual leona, ¿quién le hará alzar?» (Gén. 49, 9).

En mi opinión, tanto la relación de las mujeres compostelanas del León y del Racimo de Uvas con el célebre relieve tolosano Signum Arietis, Signum Leonis (fig. 24) como su contenido sacrifical y pascual vendría corroborado por la inscripción que figura en el reverso de una tardía cruz potenzada en madera policromada conservada en el Museu Nacional d'Art de Catalunya: la Cruz de la iglesia parroquial de Sant Feliu de Bagergue (Alt Aran, Vall d'Aran) (ca. 1200) (fig. 25) ${ }^{63}$. En los cuatro brazos del reverso de esta se lee: «OH AGNU(S)/ D(E)I Q(U)I TOLLI(S)/ [PECCATA M]U(N)/DI MISERERE / NOBIS» (Oh, Cordero de Dios, que quitas los pecados del mundo, ten piedad de nosotros), acompañado en tres de sus extremos de las palabras: «SER]PE(N)S» (abajo)/

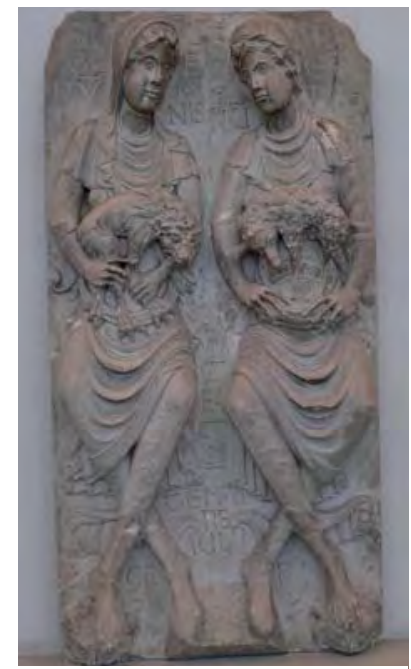

Fig. 24. Signum Leonis, Signum Arietis, ca. 1100-1105. Toulouse, Musée des Augustins.

63 J. Camps (ed.), El esplendor del Románico. Obras maestras del Museu Nacional d'Art de Catalunya, Madrid, 2011, ficha n. ${ }^{\circ} 23$, pp. 146-147. 


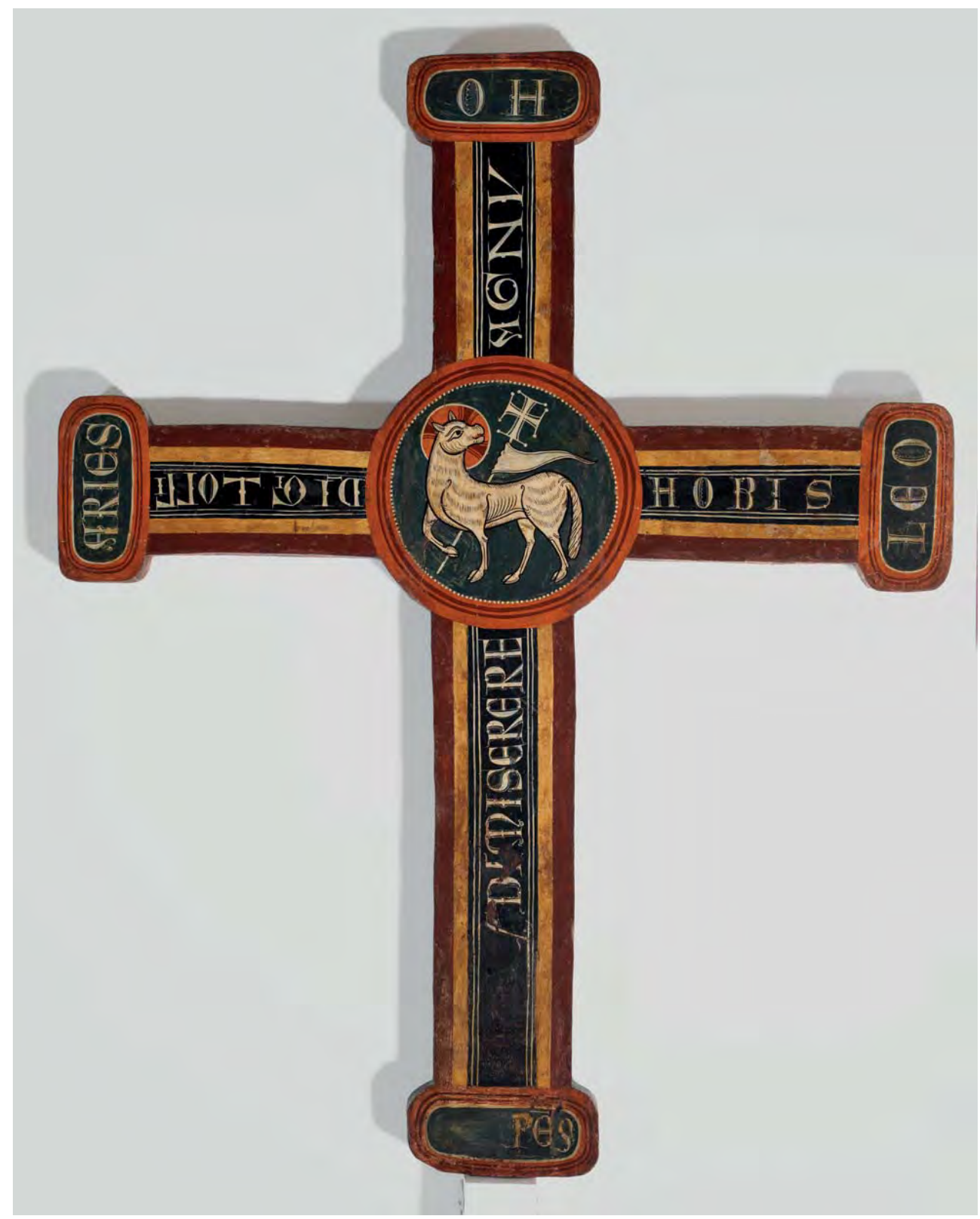

Fig. 25. Cruz pintada de Bagergue (Alt Vall d'Aran), ca. 1200. Barcelona, Museu Nacional d'Art de Catalunya. 
«ARIES» (izquierda)/ «LEO» (derecha). En el centro, un medallón central, con la representación del Agnus Dei, con el nimbo crucífero y llevando el vexillum regis, preside la composición. Se trata, sin duda, de una cruz de uso pascual, que celebra la victoria de Cristo sobre la muerte, acompañada de la invocación al Cordero de Dios que se recita en la misa en el momento de la Eucaristía. El carácter triunfal del programa se haría así explícito a través de un peculiar bestiario simbólico, consistente en la serpiente a los pies de la cruz — literalmente pisada por Cristo siguiendo el versículo 90, 13 («Super aspidem et viperam gradieris»)— así como en la exaltación de la doble naturaleza humana (Aries) y divina del Señor (León). Aunque la Cruz de Bagergue responde a un contexto diferente al tolosano y compostelano, pues se trataba de la respuesta de la diócesis de la Seu d'Urgell a la herejía cátara a fines del siglo XII, la cual negaba los dogmas de la Eucaristía y la naturaleza humana de Cristo, dicha pieza aranesa desvela ciertos usos de la imagen alegórica de Cristo perfectamente transportables a inicios del siglo XII. Así, la presencia en los programas hispano-tolosanos de figuras femeninas con el león, el carnero y las uvas buscaba igualmente una contundente afirmación de los citados dogmas pero en el peculiar contexto de la afirmación de la Reforma Gregoriana y la lucha contra Berengario de Tours ${ }^{64}$.

En conclusión, si la asociación monumental entre un ciclo del Génesis y de los Meses ofrecía la posibilidad de la redención del pecado a través del trabajo, la esperanza en la próxima venida del Mesías y su victoria sobre la Muerte se expresaba a través de su prefiguración en David e Isaac, así como en los atributos femeninos del León de Judá y de la Vid del sacrificio eucarístico. Por último, el contenido de este mensaje de redención se hacía explícito en el relieve de la Anunciación del tímpano.

Como si se tratase de un gran decorado, el programa iconográfico de la primitiva puerta norte participaba plenamente del carácter funcional y simbólico del espacio urbano que definía. La plaza, denominada Paradisus, no solo era una emulación del Paraíso del antiguo San Pedro de Roma, sino que además intentaba

64 Recientemente he desarrollado esta argumentación en el paper, «Paradise Lost: the Porta Francigena and the Beginning of the Great Portals in Romanesque Art», en la sesión del Working Group in Medieval Sculpture II: Objecthood and Installatio, organizada por Robert Maxwell, dentro del $47^{\text {th }}$ International Congress on Medieval Studies, May 10-13, 2012, Western Michigan University, Kalamazoo (Michichan), EE.UU. Dicho texto se publicará en el próximo número de la revista Iconographica, XIII, 2014 (en prensa). 
evocar el aspecto del Edén bíblico. Dicho locus amoenus se significaba a través de una fuente - la fons vitae — coronada por cuatro leones, de cuyos caños manaba el agua a la manera de los Ríos del Paraíso (fig. 2), así como por el empleo en el frontispicio de la fachada de hermosas lastras con decoración vegetal junto a relieves historiados con el ciclo de la Caída de Adán y Eva. Por esta razón, Serafín Moralejo no dudó en proponer que el programa iconográfico de la fachada y su entorno urbano constituían el marco adecuado para la celebración de los ritos penitenciales del Miércoles de Ceniza y su posterior reconciliación durante la Semana Santa ${ }^{65}$.

\section{TRAS LAS HUELLAS DE LA CONEXIÓN ROMANA: LAS COLUMNAS ENTORCHADAS}

No es mi intención volver a exponer aquí, una vez más, mi hipótesis sobre las columnas entorchadas de la desaparecida puerta norte ${ }^{66}$ sino señalar sus posibles vías de estudio. Con gran acierto, S. Moralejo había visto en ellas una evocación de la célebre pérgola apostólica en el altar mayor de San Pedro de Roma, con fustes helicoidales decorados con putti vendimiadores ${ }^{67}$. No obstante, un estudio detenido de los motivos de los fustes compostelanos con esta temática me ha llevado desde hace años a señalar su similitud con las interpretaciones contemporáneas de las columnas de San Pedro realizadas a fines del siglo xI por los marmolistas romanos, como las conservadas en Santa Trinità dei Monti (Roma) y en San Carlo a Cave (Lacio) (ca. 1093) ${ }^{68}$, y no tanto al modelo vaticano. De hecho, tal y como

65S. Moralejo, "La imagen arquitectónica de la Catedral de Santiago», en Il Pellegrinaggio a Santiago de Compostela e la letteratura jacopea. Atti del Convegno Internazionale di Studi, Perugia, 1983, Perugia, 1985, pp. 37-61.

66 El tema ha sido tratado por mí en trabajos precedentes: «Roma e il programma riformatore », «Didacus Gelmirius».

67 S. Moralejo, «Saint-Jacques de Compostelle. Les Portails retrouvés de la cathédrale romane», Les dossiers de l'archeologie, 20 (1977), pp. 87-103; «La imagen arquitectónica de la Catedral de Santiago» y «El patronazgo artístico del arzobispo Diego Gelmírez».

68 Para la datación de las columnas salomónicas romanas, véase: P. C. Claussen, «Römische Slulptur aus der zweiten Hälfte des 11. Jahrhunderts», en Patrimonio artístico de Galicia y otros estudios. Homenaje al Prof. Dr. Serafin Moralejo Álvarez, vol. 3, Santiago de Compostela, 2004, pp. 71-80; Ídem, «Un nuevo campo della storia dell'arte. Il secolo XI a Roma», en Roma e la Riforma gregoriana. Tradizione e innovazione artistiche (XI-XII secolo), Viella, Roma, 2007, pp. 61-71. Para una estado de la cuestión del estudio de dichas columnas, 
hemos señalado, las columnas compostelanas fueron realizadas probablemente poco después de 1100, tras el primer viaje de Gelmírez a Roma para recibir delante de la pérgola de San Pedro del Vaticano la dignidad de subdiácono. Con toda probabilidad, el séquito de Gelmírez tuvo acceso en sus visitas a la Ciudad Eterna a un modelo o cartón que circulaba desde fines del siglo XI en los talleres de los marmolistas romanos. De hecho, es evidente la similitud entre los esquemas compositivos y ornamentales de las columnas medievales romanas y los fustes compostelanos. Este es el caso, por ejemplo, del amorcillo vendimiador junto a un ave, de los putti que comen de un racimo, de las alimañas que muerden la viña o de las aves que pican las uvas.

Evidentemente la factura y ejecución de las columnas romanas y compostelanas es muy diversa, puesto que el estilo del Maestro de las Columnas Entorchadas tiene mucho que ver con la tradición volumétrica jaquesa, marcada por la organicidad y la vocación relivaria, frente al schiacciato o aplanamiento de los marmolis-

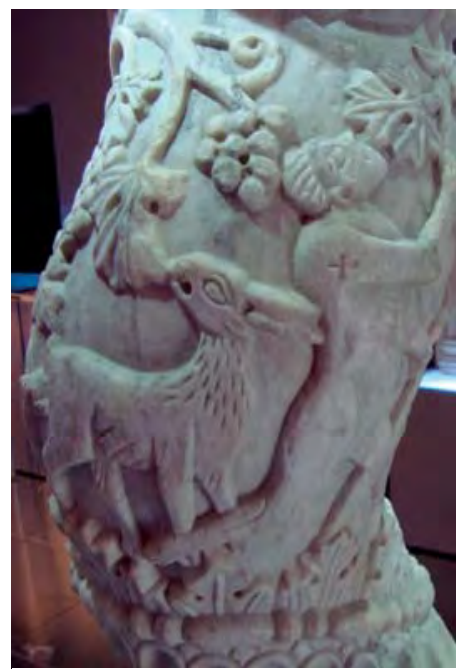

Fig. 26. Santissima Trinità dei Monti, columna salomónica, ca. 1090-1100. tas de Trinità y Cave. No obstante, en ambos casos se trata de claras derivaciones de estilos antiguos, presentes en sarcófagos de los siglos II y III d.C. El Maestro de las Columnas Entorchadas enriqueció su repertorio gracias al conocimiento directo de estas interpretaciones medievales de las columnas de la pérgola de San Pedro, que buscaban subrayar en la elección y reiteración de motivos un significado eclesiológico acorde con los ideales de la Iglesia Romana de fines del siglo XI, de clara oposición entre el bien (los vendimiadores) y el mal (alimañas, aves, serpientes, lagartijas). Ese combate llega a ser ejemplificado perfectamente en Trinità dei Monti a través de un vendimiador

Carlo a Cave», en Miche della chiesa della Santissima Trinità dei Monti a Roma e di San fichas cat. n. ${ }^{\circ} 19-20$, pp. 346-348. Cabe señalar también el análisis realizado por S. Trinks de las columnas entorchadas compostelanas, que pone de manifiesto su deuda con el repertorio dionisíaco romano y las Metamorfosis de Ovidio, si bien no podemos compartir su datación en 1117 (Antike unt Avantgarde. Skulptur amb Jakobsweb im 11. Jahrhundert: Jaca-León-Santiago, Berlín, 2012, pp. 252-267; 332-344). 
que lleva su hombro «tatuado» con la Cruz de Cristo (fig. 26).

No cabe duda alguna de que este mensaje se entiende perfectamente en Santiago, pues en el Liber Sancti Iacobi (I, 6), en el Sermón de la Pasión del Apóstol (25 de julio), se habla de las barbarae ferae y de las vulpes hereticae - que pululan en las columnas de Cave, Trinità dei Monti y Santiago-, como enemigos del apostólico vendimiador de la Viña de la Iglesia. Otro tanto se puede afirmar de la representación de los pájaros de otro de los fustes compostelanos que, como en los ejemplares romanos, pican con maldad la viña. No obstante, en el caso de Compostela en una de las columnas un amorcillo atrapa con fuerza una paloma por el cuello para proteger su afanoso trabajo (fig. 27) en directa correspondencia con el contenido de los versos de un himno de



Fig. 27. Maestro de las Columnas Entorchadas: fragmento de fuste entorchado procedente de la primitiva Porta Francigena: 1101-1111. Museo da Catedral de Santiago. san Fortunato recogido en el mismo sermón del Calixtino:

La uva hinchada en el pámpano, que pasto
sería de los pájaros, con este
guardián el buen lagar no ha de perderla ${ }^{69}$.

La primitiva Porta Francigena parecía adherirse así, de manera muy directa y particular, al ideario del arte de la Reforma Gregoriana haciendo una cita explícita a la Roma papal. Es esa voluntad estético-ideológica, propia de una sede pretendidamente apostólica, la que permite destacar la primitiva puerta compostelana de otros monumentos escultóricos emergentes entonces fuera de Roma, que también se sumaban entonces al ideario reformista, como la Porte Miègeville o la fachada occidental de la Catedral de Módena. 


\section{LOS ENIGMAS DE LA PUERTA DE PLATERÍAS}

Desde el año 1995, he dedicado numerosos trabajos al problema de la fachada del brazo sur del crucero de la Catedral de Santiago. En su día, resultaron novedosas algunas aportaciones, en particular su primitiva función como puerta de la representación del poder del obispo de Compostela. Para ello, me basaba en tres hechos incuestionables: la existencia en esta platea sur del primer palacio de Gelmírez, antes de que éste se trasladase a su actual ubicación en el lado norte de la catedral; las noticias que corroboraban que allí todos los viernes se celebraban juicios presididos por el prelado compostelano; el trasfondo «reformista»y "gregoriano» de sus temas iconográficos en relación con la colección de cánones Polycarpus, dedicada a Gelmírez por el Cardenal Gregorio de San Crisógono ${ }^{70}$. Más allá de estas apasionantes cuestiones, en los últimos años he ahondado en un problema de fondo relativo a la realización de la fachada ${ }^{71}$ : la posible existencia de un proyecto previo, distinto al actual y nunca llevado a cabo en traza arquitectónica, pero para el cual se labraron algunas piezas atribuibles al denominado Maestro de Conques o de las Tentaciones, formado en el taller escultórico del abad Bégon III (1087-1107) de la abadía de Santa Fe de Conques.

Antes de iniciar un comentario pormenorizado de todos estos temas, cabe recordar una vez más que, según la tradición, Platerías debe su nombre a las tiendas de los plateros establecidos en los bajos de dicha plaza al menos desde época moderna. No obstante, tanto el aspecto como la dedicación comercial de la plaza de Praterías difieren de su articulación medieval primigenia. Aunque quedan todavía muchos enigmas por resolver, a falta de una excavación sistemática en su entorno urbano, podemos afirmar que su frontis ha sufrido diferentes alteraciones e intervenciones prácticamente desde su concepción y que, como veremos, en un primer momento funcionó como Puerta de representación del Obispo Compostelano, en un urbanismo menos amplio y que en su momento estaba más directamente conectado con la actual Rúa do Vilar.

70 M. Castiñeiras, «Un adro para un bispo: modelos e intencións na fachada de Praterías», en A. Vigo Trasancos (ed.), Cultura, poder y mecenazgo, Universidade de Santiago de Compostela, Santiago, 1998, pp. 231-264.

71 M. Castiñeiras, «Didacus Gelmirius». 
Por lo que respecta a su frontis, afortunadamente conservamos dos descripciones de su estado anteriores al siglo XVIII. La primera y la más célebre, es la de la Guía del Códice Calixtino, un libro redactado hacia 1137, es decir, por alguien perteneciente a una generación contemporánea o inmediatamente posterior a la finalización de la fachada en 1111. La segunda descripción, menos conocida, pero más cercana a cierta percepción del espectador actual, es la de Mauro Castellà Ferrer en su Historia del Apóstol de Jesús Christo Santiago Zebedeo, publicada en $1610^{72}$. Este último compara ya la fachada con un verdadero «museo lapidario», al que se le fueron añadiendo progresivamente piezas de otros lugares, antecediendo así a la visión que, siglos más tarde, expresará el gran historiador del arte francés Henri Focillon a propósito de Platerías ${ }^{73}$. Dicha categoría resulta incuestionable puesto que, como veremos, desde fechas muy tempranas sus muros fueron destino de piezas procedentes de otras fachadas, soportaron en dos ocasiones las consecuencias de un asedio y sufrieron al menos tres restauraciones medievales. De ahí su condición de "palimpsesto de piedra»: su vida ha sido como la de un pergamino, cuyas letras se han perdido en gran parte a causa de la insidia del tiempo, pero también por la voluntad de «lavarlo» con el objeto de volver a rescribir su historia.

\section{Platerías: del proyecto frustrado del Maestro de Conques (1101-1103) a un segundo proyecto (1103-1111)}

La impresión de rompecabezas que se desprende de la disposición de las lastras de la fachada — con sus roturas y variaciones de tamaño y forma — responde en parte a las sucesivas alteraciones de un proyecto original que, posiblemente, ya desde su propia gestación presentó algún desajuste entre su traza arquitectónica y su decoración. De hecho, las tres arquivoltas exteriores de las puertas dobles se interseccionan en la enjuta central antes de llegar a la base, una fórmula inaudita para la época, lo que provocó que tanto el Crismón como la pareja de leones pensados para embellecer dicho lugar no tengan espacio suficiente y sobresalgan del muro. Se trataba de algo absolutamente diferente a lo que se veía en la fachada del

72 M. Castellá Ferrer, Historia del Apóstol de Iesus Christo Sanctiago Zebedeo, Patrón y Capitán General de las Españas, 1610, 464v-465r (reimpr. Santiago, 2000) (en adelante HA).

$73 \mathrm{H}$. Focillon, La escultura románica. Investigaciones sobre la historia de las formas, trad. esp. Madrid, 1986, p. 46 (1a ed. fr. 1931). 
brazo norte del transepto, cuya puerta bífora tenía sus arquivoltas perfectamente separadas en un holgado espacio.

En Platerías se habría buscado pues, conscientemente, potenciar el espacio de los tímpanos en sacrificio de la armonía de una bífora que, en vez de estar diferenciada, se construyó interseccionada en su centro. De hecho, la solución más lógica hubiese sido, como en la Porte des Comtes o en la puerta occidental de Toulouse, haber mantenido una bífora perfecta, siguiendo el esquema de las trece columnas de la puerta norte, cuyas columnas interiores se alineaban pareadas $(1+2 / 2+1 / 1$ (pilastra) $/ 1+2 / 2+1$ ), y que suponía unos tímpanos de espacio muy reducido. Por el contrario, en Platerías las columnas se reducen a once, quitando dos de cada lado del machón central, y aparecen siempre escalonadas: $3 / 2+1+2 / 3$ (fig. 10).

En el caso de la primitiva Porta Francigena, los tímpanos no supusieron ningún problema de diseño ya que su decoración, tal y como se lee en la descripción del Calixtino, era mínima. Tan solo el de la izquierda estaba esculpido con una sencilla lastra de mármol con la Anunciación — Gabriel y María—, reutilizado en el siglo XVIII en el frontispicio de Platerías. Este antiguo tímpano pertenecía sin duda a esa primitiva fase en la que la decoración figurada de los tímpanos era inexistente



Fig. 28. Reconstrucción hipotética del primer proyecto de bífora de la fachada de Platerías de la Catedral de Santiago, nunca realizado (1101-1103). Dibujo: Victoriano Nodar bajo asesoría de M. Castiñeiras.
- Porte des Comtes - o al menos titubeante $^{74}$. Como en el portal occidental de Jaca, se trata de lastras de formato rectangular que tienen una mala adecuación con el formato semicircular.

No sabemos cómo ni cuándo, pero intuimos que en esos años iniciales del siglo XII se produjo una encarnizada discusión sobre la decoración de los tímpanos de Platerías que dio lugar a la formulación de dos proyectos consecutivos. En el primer proyecto (fig. 28), se pretendía respetar en Platerías la anchura de la puerta y de los tímpanos de la Francigena. En mi opinión,

74 Moralejo, «La primitiva puerta norte», p. 648. 
el taller que trabajó para esta primera decoración de la fachada sur estaba dirigido por el denominado Maestro de las Tentaciones o de Conques, el cual realizó sus relieves con la idea de colocarlos en un proyecto truncado, que nunca se llevó a cabo. Este consistía en dos tímpanos más pequeños y menos atiborrados de figuras, trece soportes (12 columnas y pilastra) y una bífora perfectamente separada ${ }^{75}$. Los relieves se realizaron pero no la traza arquitectónica para la que habían sido pensados. De ahí los desajustes actuales del tímpano izquierdo, en los que los contornos superiores de los cuatro relieves que conforman las Tentaciones de Cristo sugieren, tal y como señaló O. Naesgaard ${ }^{76}$, el ser pensados para el arco de una semicircunferencia menor, pero que, al montarse finalmente en una estructura que le daba mayor espacio del tímpano, este tuvo que rellenarse con otras tantas lastras que le confirieron ese aspecto caótico que lo caracteriza (fig. 29). El segundo proyecto (fig. 30), que originó la traza arquitectónica que vemos en la actualidad, le otorgaba más protagonismo a los tímpanos, con lo que estos tuvieron que ser rellenados con el recurso a otro maestro:

75 Dicha hipótesis fue por primera vez formulada por mí en: «La catedral románica: tipología arquitectónica y narración visual», en Manuel Núñez Rodríguez (ed.), Santiago, la Catedral y la memoria del arte, Consorcio de Santiago, Santiago, 2000, pp. 39-96, espec. p. 56.

76 O. Naesgaard, Saint-Jacques de Compostelle et les débuts de la grande sculpture vers 1100, Aarhus, 1962 , p. 16. 
mientras que los relieves de las Tentaciones se adjudican al denominado Maestro de Conques, el caótico relleno debe atribuirse al denominado Maestro de la Porta Francigena, que era, como su nombre indica, el gran artífice de la decoración de la fachada norte (Creación de Adán, David, Mujer del León y del Racimo de Uvas,

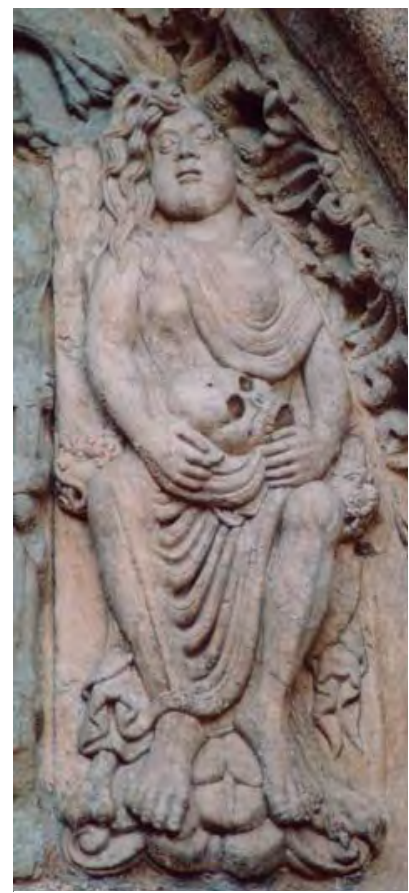

Fig. 31. Catedral de Santiago, fachada sur, tímpano izquierdo: Maestro de la Porta Francigena, Mujer de la Calavera, 1101-1111. Mes de Febrero) y que colocaría en la parte derecha del ingreso izquierdo de Platerías, entre otros, los siguientes relieves: los tres diablos cinocéfalos en las Puertas del Infierno, el sonador del cuerno que cabalga al león y una solitaria Mujer de la Calavera.

Muy probablemente la estatua de la misteriosa Mujer de la Calavera (fig. 31) (y sus compañeros infernales) ${ }^{77}$ fueron originalmente pensados para el tímpano derecho de la primitiva puerta norte, como contrapunto de la Anunciación que decoraba el tímpano izquierdo de la bífora. De hecho, su contenido profano y moralizante - en ocasiones leído como una evocación de Eva- enlazaría con las lastras dedicadas a las consecuencias del Pecado Original (Centauro-Sagitario, Sirena, Ballestero, Hombre cabalgando el gallo) que se situaban en el friso sobre el ingreso derecho. Aunque recientemente había propuesto para la impactante Mujer de la Calavera una conexión directa con el ciclo de los desdichados amores de Tristán e Isolda que, según S. Moralejo, decoraban una de las columnas entorchadas de la primitiva puerta norte conservada en el Museo de la Catedral, he tenido que revisar y matizar mejor esta vía de interpretación para el relieve y subrayar su relación con el citado sermo rusticus que acompañaba el friso del Génesis de la primitiva puerta norte. En efecto, la vieja lectura «épico-caballeresca» del fuste defendida por Moralejo ha querido ser substituida en los últimos años por la interpretación de F. Prado-Villar, que ve en éste una representación del episodio de Ulises y las sirenas

77 S. Moralejo, «Artes figurativas y artes literarias en la Espańa medieval: Románico, Romance y Roman», Boletín de la Asociación Europea de Profesores de Español, xvII, 32-33, 1985, pp. 61-70, espec. p. 66. 
en la Odisea basándose en tres elementos: la colocación del protagonista desfallecido o dormido en una barca, el hecho de que el personaje identificado como Ulises tape, en otras escenas (fig. 19), con una mano el oído de uno de sus compańeros y, por último, la comparecencia de la feroz Escila y de la seductora sirena. No cabe duda, como sugiere Prado-Villar, de que el autor de la columna se inspiró directamente en una figuración de la historia de Ulises y las sirenas, tan común en los sarcófagos paganos del siglo $\mathrm{III}^{78}$. No obstante, el resultado final parece más el fruto de una inspiración medieval en esquemas clásicos, en los que, siguiendo el principio de disyunción panofskyana, forma y contenido se disgregan. Así, la presencia de motivos narrativos caballerescos, ligados con la matière de Bretagne, parece ineludible, tanto en el caballo que acompaña al héroe en la barca en la escena inferior, en el hecho de que el «compañero de Ulises» de la segunda escena tenga un aspecto femenino (¿Isolda?) y acaricie a un obeso guerrero (¿Tristán?), como finalmente en el combate del guerrero con las aves de rapiña para defender el cadáver de su caballo en el registro superior. Nada impide, pues, que el autor de estos relieves se haya basado en formas clásicas del mito de Ulises, que pudo contemplar en el primer viaje de Gelmírez a Roma, para poder desarrollar una historia caballeresca.

De hecho, las indagaciones realizadas en su día sobre la leyenda de Tristán me permitieron reparar en un episodio de la misma, hasta el momento desapercibido, que me ayudaba a comprender mejor el contenido de la célebre lastra de la Mujer de Platerías así como a confirmar una de sus características más obvias: su carácter intertextual, vernacular y absolutamente directo. Dichos valores, que son todavía válidos en la interpretación del relieve, se encuentran en otros programas monumentales contemporáneos del románico, como el portal occidental de Santa Fe de Conques. En este último, por ejemplo, el espectador/peregrino podía reconocer, en la absoluta variedad de sus imágenes, referencias más o menos explícitas a las historias narradas en los milagros recogidos en el Liber Sancte Fidis ${ }^{79}$. Así, en la célebre figuración del Infierno de la abadía gala, la caída del caballo del guerrero, interpretada en la Psicomaquia de Prudencio, como el castigo del Pecado Capital de la Soberbia, podía ser perfectamente leída, en clave local, como una referencia al trágico final

78 F. Prado-Villar, «Nostos: Ulises, Compostela y la ineluctable modalidad de lo visible», en Compostela y Europa, pp. 260-269.

79L. Bousquet, Le Jugement Dernier au Tympan de l'église Sainte-Foy de Conques, Rodez, 1948, p. 42. 
del caballero Rainon, señor de Aubin, que, según el Libro de los Milagros de Santa Fe (I, 5), se había apoderado previamente de los bienes y terrenos de la abadía ${ }^{80}$.

De hecho, el Maestro de la Porta Francigena, autor indiscutible de la Mujer de la Calavera y de las lastras del Infierno, parece haber aprendido a conferir a sus lastras la categoría de "parlantes» a partir de su contacto con el Maestro de Conques (o de las Tentaciones) que trabajó en el primer proyecto de Platerías. Ello explicaría el tratamiento vernacular que se hace del Pecado de la Lujuria en la representación compostelana, perfectamente acorde con el género de los exempla ${ }^{81}$ y que se constata desde fechas muy tempranas en la literatura tristaniana. En efecto, en una de las versiones más antiguas de la leyenda, el Tristán de Thomas, escrita por un clérigo anglonormando hacia 1155 en la corte de Leonor de Aquitania, se incluía la referencia al exemplum libidinis encarnado por el relieve compostelano: el del amante asesinado por el marido de la mujer adúltera y su consiguiente castigo. Así, en el Tristán de Thomas, Isolda — una vez casada con el rey Mark de Cornualles— entonaba, acompañada al arpa por Tristán, el trágico Lai de Guirun, que narraba la historia de un amante asesinado por el esposo de la amada, la cual fue obligada después a comer su corazón servido a la mesa (vv. 781-790):

En sa chambre se set un jor

E fair un lai pitus d'amur:

Coment dan Guirun fu surpris,

Pur l'amur de la dame ocis

Qu'ils sur tute rien ama,

E coment li cuns puis li dona

80 «Il allait bientôt les atteindre, lorsque, par un effet de la vengeance divine, son cheval se renverse subitement, les sabots en l'air, la tête dans la poussière. Le cavalier, précipité en avant, est projecté au loin avec une tell violence, qu'il périt le cou torduet le crâne fracassé et mi en pièces [...] Quel spectacle, pour un écolâtre tel que moi, de contempler l'Orgueil, non dans l'abstraction, com je l'ai lu dans la Psychomachie de Prudente, mais substantiellement incarné dans un corps, étendu terrassé, et précipité sans retour du fait de son faste superbe dans le gouffre sans fond du grand abîme, creusé perfidement sous ses pieds par le piège du péche!», Liber Miraculorum Sancte Fidis, I, v (De celui qui, en se précipitant sur un moine de sainte Foy, fit une chute où il trouva la mort), L. Servières y A. Boulliet, Sainte Foy. Vierge et martyre d'Agen, II, Agen, 1900-1901, 458. Cfr. Bousquet, "Jugement», pp. 43-46; J.-C. Bonne, L'art roman de face et de profil. Le tympan de Conques, Aleçon (Orne), 1985, pp. 203-204; Castińeiras, «Da Conques a Compostella», p. 242.

81 J. Williams, «La Mujer del Cráneo y la simbología románica», Quintana, 2, 2003, pp. 13-27. 


\section{Le cuer Guirun a sa moillier}

Par engin un jor a mangier,

\section{E la dolur que la dame out \\ Quant la mort de sun ami sout ${ }^{82}$.}

Ese mismo Lai Guirun se recoge, años más tarde, en el Tristán de Gottfried von Strassburg (1205-1210), pero esta vez Tristán se conmueve en presencia de su tío Marke de Cornualles al escuchar la interpretación de esta bella melodía por parte de un harpista galés:

Ocurrió un día, poco después de comer, en el lugar donde era costumbre que se sentaran a charlar, que estaba Marke escuchando atentamente una melodía interpretada por un arpista, un maestro de su especialidad y el mejor que se conocía. Procedía de Gales. Tristán de Parmenia vino a sumarse a ellos, sentándose a los pies del rey para escuchar interesado la melodía y los tonos deliciosos. Incluso aunque se lo hubiesen prohibido bajo amenaza de muerte, no habría podido ocultar que estaba muy conmovido y que el corazón se le colmaba de añoranza. Dijo: «Maestro, tocáis bien. Las notas están bien reproducidas, con sentimiento y tal y como fueron pensadas. Fueron escritas por bretones que trataron acerca del Señor Gurún y de su amada» ${ }^{83}$.

82 Dicho texto se conserva en el manuscrito Sneyd (s. XII), el más antiguo de las versiones conservadas de Thomas (Thomas, Les fragments du Roman de Tristan. Poème du Xİ̈ siècle, ed. B. H. Wind, Ginebra-París, 1960, pp. 64-65). La leyenda de un marido que mata al amante de su mujer y le extrae el corazón que después da de comer a esta, que muere de dolor, se aplicó también al trovador rosellonés Guillem de Cabestany, cuyo corazón fue servido a Saurimonda, esposa de Ramon de Castell Rosselló, al trouvère Le Chatelain de Coucy y al Minnesänger Reinmar von Brennenberg y L. Rossi, «Il cuore, mistico pasto d'amore: dal "Lai Guirun" al Decameron", en G. Tavani (dir.), Studi Provenzali e Francesi 1982, L'Aquila, 1983, pp. 28-128; J. Paredes, «Del "utile consiglio" y las "sollazzevoli cose”. El Decameron en el marco de la cultura popular», Cuadernos de Filología Italiana, 2001, pp. 119-136. En el Decamerón (Iv, 9, Milano, 1987, pp. 314-317), además de recogerse la leyenda de Guillem de Cabestany, se incluye una curiosa versión del exemplum (Iv, 5, ed. cit., pp. 294-297), especialmente sugerente para comentar la Mujer de Platerías, en el que una pobre Isabetta di Messina, cuyo amante fue asesinado y enterrado por sus hermanos, consigue exhumar la cabeza del amado, que encierra en un tiesto con albahaca, donde cada día llora, hasta que uno de sus hermanos la priva de tal objeto, y la joven muere de pena.

83 Se trata de una vieja canción bretona sobre la suerte del Señor Gurún y su amada, conocida como el Lai de Guiron, Gottfried von Strassburg, Tristán e Isolda, Bernd Dietz (trad.), Madrid, 1987, p. 7, p. 48. 
Como en los textos literarios, en ese primitivo contexto de la Porta Francigena, la imagen cobraría todo su sentido, ya que serviría de exemplum libidinis de las consecuencias del Pecado Original, como contrapunto de la María de la Anunciación y como compañera de las lúbricas figuras de la Sirena, el Hombre cabalgando el gallo y el violento ballestero. La Mujer de la Calavera, en su exilio de Platerías, no habría, sin embargo, perdido nunca su contenido moralizante ya que, según la Guía del Códice Calixtino (v, 9), sobre ella se realizaba siempre un comentario, nada ajeno al contenido vernacular de los lais cantados por Tristán:

Y no ha de relegarse al olvido que junto a la tentación del Señor está una mujer sosteniendo entre sus manos la cabeza putrefacta de su amante, cortada por su propio marido, quien la obliga dos veces por día a besarla. ¡Oh cuán grande y admirable castigo de la mujer adúltera para contarlo a todos! ${ }^{184}$.

Volviendo al primitivo proyecto de Platerías, quisiera llamar la atención sobre ese Maestro de las Tentaciones o de Conques, indudable deudor del estilo de Conques de la época del abad Bégon III (1087-1107) y que seguramente también trabajó en el gran portal occidental de la abadía francesa ${ }^{85}$. Este se caracteriza por sus figuras con cabezas cúbicas, el pelo a la taza, anchas narices, corto canon, pliegues planchados, así como el recurso al uso del perfil y el tres cuartos con tendencia al bulto redondo, una extensa variación en la posición de los pies sobre cornisas así como un gusto por las inscripciones, el anacronismo de los ropajes y la representación de objetos de orfebrería. Dicho escultor utiliza además en Compostela como piedra preferente de sus relieves la serpentina, la cual también se constata en las mismas fechas en Conques en el seno del taller del abad Begón III.

No por casualidad, este maestro fue el encargado de decorar los dos tímpanos de Platerías en su primer proyecto. De hecho, en el luneto derecho las lastras que podemos atribuirle - la Coronación de Espinas con la Flagelación y la Epifanía- formaban en origen la composición del mismo (fig. 15). Se trata de tres

84 CC, v, 9, p. 562.

85 Esa misma filiación ha sido defendida por J. Williams, «Framing Santiago», en C. Hourihane (ed.), Romanesque. Art and Thought in the Twelfth Century. Essays in Honor of Walter Cahn, Index of Christian Art-Department of Art \& Archaeology, Princeton University-Penn State University Press, 2008, pp. 219-238. Véase también Castińeiras, «Da Conques a Compostella». 
lastras rectangulares, una ligeramente más ancha y alta, pensada para el registro inferior (Coronación-Flagelación), y la otra, más baja y estrecha, pensada para colocarse sobre ellas en el registro superior. Ambas se ensamblarían perfectamente, de manera que la Virgen se colocaría, en el centro de la semicircunferencia, sobre la columna de la Flagelación, tal y como parece indicar el pedestal que sostiene sus pies. Sin embargo, con el cambio de plan y la realización de tímpanos más amplios, la lastra de la Epifanía se colocó de forma diversa, corrida hacia la derecha, de manera que la Virgen, pensada para el cenit de la semicircunferencia, no cupo en el espacio en el que fue colocada - en el inicio del descenso de la curva-, con lo que hubo que cortarle el nimbo y rasurarle el pedestal.

En este Tímpano de la Infancia y Pasión de Cristo hubo que recurrir también, como en el anterior, a la ayuda de un segundo maestro que también había sido muy activo en la Porta Francigena: el Maestro de la Traición. Dicho maestro es muy narrativo y se caracteriza por sus rostros ingenuos, con pupilas excavadas rellenas de pasta vítrea y grandes bigotes, así como por sus pliegues gruesos que se ciñen a la parte inferior del cuerpo y su tendencia al bulto redondo en las figuras en tres cuartos. Responsable en gran parte de las escenas más dramáticas del ciclo del Génesis de la puerta norte — Reprensión de Adán y Expulsión de Adán y Eva—, se encargó de «rellenar» el primitivo proyecto del tímpano derecho de Platerías (Ciclo de la Pasión) con las siguientes escenas: a la derecha, Prendimiento de Cristo y el Ángel con la Corona en picado; arriba, en el centro, el ángel en postura serpentinata que sobrevuela a los Reyes Magos; y, finalmente, a la izquierda, la lastra de la Curación del Ciego. Todos estos relieves poseen un canon más alargado, están enganchados en la pared por medio de grapas de hierro y, en el caso de los inferiores, carecen de la sólida cornisa que señala la línea de tierra en el Maestro de Conques. Las grapas de hierro llamaron precisamente la atención de Castellá Ferrer a principios del siglo XviI como prueba evidente de que no se hicieron para allí:

[...] porque no entran por las paredes de adentro, sino que en hierros que metieron entre ellas (porque son delgadas) encaxando los mismos hierros en la pared, las pusieron en ella, de suerte, que pudieron sustentarse como ahora se vee; y algunas descarnándolas las aguas se han caydo, quedándose allí los hierros como se vee donde estuvieron ${ }^{86}$. 
No obstante, esta sistematización de los relieves con grapas de hierro, visible en Platerías, se encuentra contemporáneamente en la Porte Miègeville de Toulouse y responde a técnicas propias del románico.

Por lo tanto, el resultado final de Platerías obedece, en un principio, a una mala adecuación entre un primer proyecto de tímpanos pequeños, cuya decoración fue encargada al Maestro de Conques, y un segundo proyecto, inmediato, que buscaba un ingreso más ancho y que provocó la ampliación del espacio de los tímpanos y su forzoso «relleno» con otras lastras, realizadas por los denominados Maestros de la Porta Francigena y de la Traición. Por ello, puedo afirmar que el caos de Platerías no fue inicialmente buscado y que el fracaso de su sistematización no estaba previsto en su primera intención y es, pues, fruto de cierta improvisación.

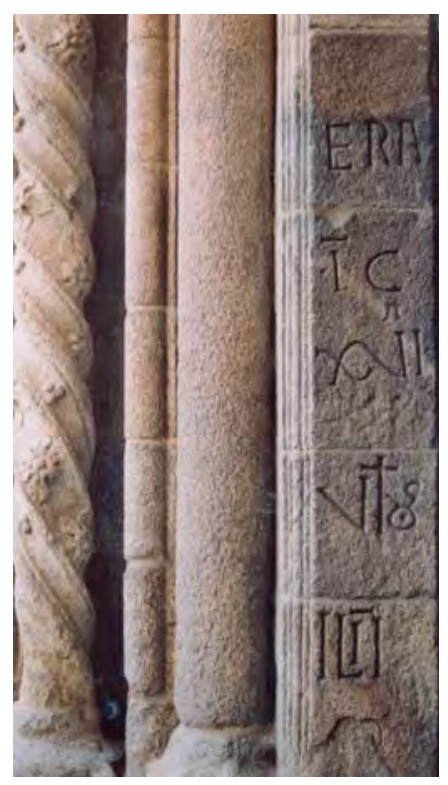

Fig. 32. Catedral de Santiago, fachada sur, ingreso derecho, jamba izquierda: inscripción.

Pero ¿cuándo se produjo el cambio de proyecto? Según la Historia Compostelana, Gelmírez decidió erigir su primer palacio tras su consagración episcopal, el 21 abril de $1101^{87}$. Este se alzaba en el espacio contiguo de lo que será el Portal de Platerías, en un lugar que se denomina platea en los documentos, ya que comportaba la elevación de una plataforma, con el objeto de cimentar el área del palacio y de la fachada sur de la catedral, los cuales miraban desde lo alto a la ciudad ${ }^{88}$. En mi opinión, la controvertida inscripción de las jambas del ingreso derecho de Platerías daría la clave del inicio de la elevación de la fachada de Platerías. No obstante, es cierto que desde un punto epigráfico la lectura de la inscripción es la siguiente: «Era ICXVI/ IDVS I(V)LII M(agister)/ Q(ui) F(ecit) O(pus)» (11 de julio de la era 1116 [1078], el Maestro que hizo esta obra) (fig. 32). Así la han interpretado J.

87 HC, I, 20, p. 110.

88 F. López Alsina, «Implantación urbana de la catedral románica de Santiago de Compostela (1070-1150)», en F. Singul (ed.), La meta del Camino de Santiago. La transformación de la catedral a través de los tiempos, Consellería de Cultura, Santiago, 1995, pp. 37-56, espec. 50-51. Véase también F. López Alsina, La ciudad de Santiago de Compostela en la alta Edad Media, Santiago, 1988, pp. 141, 143, 246-247. 
Williams (2008, p. 160) y J. D’Emilio (2007, pp. 17-18), basándose en las lecturas dadas por dos redactores galos del Liber Sancti Iacobi: Giraldo de Beauvais, autor del capítulo 78 del primer libro de la Historia Compostellana ${ }^{89}$, y el poitevino Americ Picaud de Parthenay —o quien se esconda bajo ese nombre-, supuesto autor de la Guía del Calixtino ${ }^{90}$. Ambos, a partir de la lectura de la inscripción de Platerías, señalaban que «la iglesia se comenzó en la era MCXvi (año 1078)». No obstante, la fecha 1078, bien como inicio de obras de la catedral, bien como celebración de la construcción de Platerías, resulta, a todas vistas, insatisfactoria, por lo que es necesario ofrecer una segunda explicación.

Para M. Gómez Moreno (1934), F. Bouza Brey (1944), S. Moralejo (1992, p. 211) y F. López Alsina (1995) el enigma de la inscripción de Platerías radicaba en el problema paleográfico del paso de la cursiva visigótica a la carolina. Partiendo de esta premisa, podría reconstruirse el proceso de su realización del siguiente modo. En primer lugar, muy probablemente el scriptor que se encargó de redactar la inscripción en papel, siguiendo usos hispánicos, unió el grupo XL en la fecha, de manera que se leía (fig. 33): «Era ICXLI/ V IDVS I(V)LII M(agister) Q(ui) F(ecit) O(pus)» (11 de julio de la era 1141 [1103] el Maestro que hizo esta obra $)^{91}$. En segundo lugar, el ordinator escribió con tiza el texto en las jambas y finalmente el sculptor, en mi opinión,

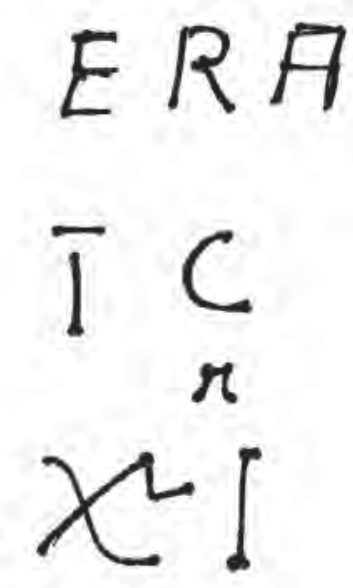

Fig. 33. Reconstrucción de la inscripción de Platerías en la versión del scriptor.

89 «Fue comenzada la nueva iglesia de Santiago, preclara y singular, en la era MCXvi (año 1078) el 11 de julio», HC, I, 78, 2, trad. cit., p. 189. Para la atribución a Giraldo de este capítulo, véase: López Alsina, La ciudad de Santiago, pp. 64-66.

90 «La iglesia se comenzó en la era Mcxvi (año 1078)», Cc, v, 9, trad. cit, p. 570. Cfr. J. D’ Emilio, "Inscriptions and the Romanesque Church: Patrons, Prelates, and Craftsmen in Romanesque Galicia», en C. Hourihane (ed.), Spanish Medieval Art: Recent Studies, Arizona Center of Medieval and Renaissance Studies-The Index of Christian Art/Princeton Universtity, Princeton, New Jersey, 2007, pp. 1-33, espec. pp. 17-18; J. Williams, «Framing Santiago». Los problemas que plantean las dos posibles lecturas de la inscripción de Platerías han sido abordados también por Jens Rüffer, Die Kathedrale von Santiago de Compostela (1075-1211). Eine Quellenstudie, Friburgo-Berlín-Viena, 2010, pp. 166-172.

91 López Alsina «Implantación urbana», pp. 50-51; S. Moralejo, «The Codex Calixtinus as an Art-Historical Source», J. Williams y A. Stones (eds.), The Codex Calixtinus and the Shrine of St. James, Tübingen, 1992, pp. 207-227. Véase también López Alsina, La ciudad de Santiago, pp. 141, 143, 246-247. 
un extranjero - posiblemente el Maestro de Conques, que realiza el resto de las inscripciones de los tímpanos en capitales clásicas-, no entendió la unión hispánica del grupo xL y lo convirtió en un $\mathrm{xv}^{92}$, provocando de esta manera un secular malentendido.

La fecha de 1103 es la única que tiene sentido en la fachada pues supondría la finalización del palacio, la nivelación de la platea sur y el inicio de la erección de Platerías. No obstante, como ya hemos comentado, Giraldo de Beauvais es el primero en interpretar de manera errónea la inscripción de Platerías como la fecha del inicio de las obras de la catedral en un capítulo que alude, sin embargo, a las obras emprendidas en el transepto por el «arquitecto» Gelmírez, con el fin de derribar la iglesia de Alfonso in en 1112 y la consiguiente elevación de un coro. Por otra parte, cuando en la Guía del Calixtino la fecha «Era 1116» (1078) vuelve a ser utilizada como comienzo de las obras, paradójicamente se pasa seguidamente a afirmar sin rubor alguno que «desde el año en que se comenzó hasta la muerte de Alfonso, famoso y muy esforzado rey aragonés, se cuentan cincuenta y nueve años» (!) ${ }^{93}$ : Alfonso el Batallador murió en 1134 , por lo tanto, se está tomando como inicio de las obras el año 1075. Es evidente, por lo tanto, que en ambos casos existe una contradicción entre el uso de la fecha y el contenido del capítulo correspondiente.

Muy probablemente, la colocación de la fecha de 1103 en la jamba de Platerías se explica en relación con otro momento constructivo de la catedral: las obras del transepto. Su trascendencia radica, además, en el hecho de que para esa fecha los relieves del Maestro de Conques estarían ya acabados. Por lo tanto, las lastras de las Tentaciones y de la Pasión de Cristo, pensadas para el primer proyecto de portada, habrían sido realizadas entre 1101 y 1103, contemporáneamente a la elevación de la platea y del primer palacio. No obstante, cuando se decide su colocación, en 1103, se optó por realizar un segundo proyecto de tímpanos más ancho, abandonando la traza del primero.

En mi opinión, el Maestro de las Tentaciones o de Conques, habría llegado a Compostela hacia 1101, posiblemente para realizar los relieves de los tímpa-

92 Agradezco, respecto al problema de la inscripción, las preciosas sugerencias realizadas por Marta Herrero de la Fuente (Universidad de Valladolid) y José Antonio Fernández Flórez (Universidad de Burgos) en el seno de las discusiones del presente congreso, las cuales me han ayudado a mejorar mi interpretación.

$93 \mathrm{cc}, \mathrm{v}, 9$, trad. cit., p. 571. 
nos de Platerías, si bien también es el responsable del célebre capitel del Castigo del Avaro del brazo sur del transepto (fig. 34). Se habría formado en el taller del abad Bégon (1087-1107), que realizó en Conques tanto los capiteles de las tribunas de la nave como la decoración del claustro, cuya finalización alrededor del año 1100 parece bastante plausible a partir de los testimonios documentales y epigráficos. Así, además de las noticias que confirman su conclusión antes de la muerte de Bégon III, en $1107^{94}$, el hallazgo del dintel pentagonal de Molinols, procedente de una de las dependencias claustrales de la abadía, sugiere una consagración hacia el año 1100 (fig. 35): «[ANNO AB IN]CARNATIONE DOMINI: MILLESIMO: C: TE[RTIO]» (El año de la Encarnación del Señor 1100, el tercer día antes de [...] $)^{95}$.

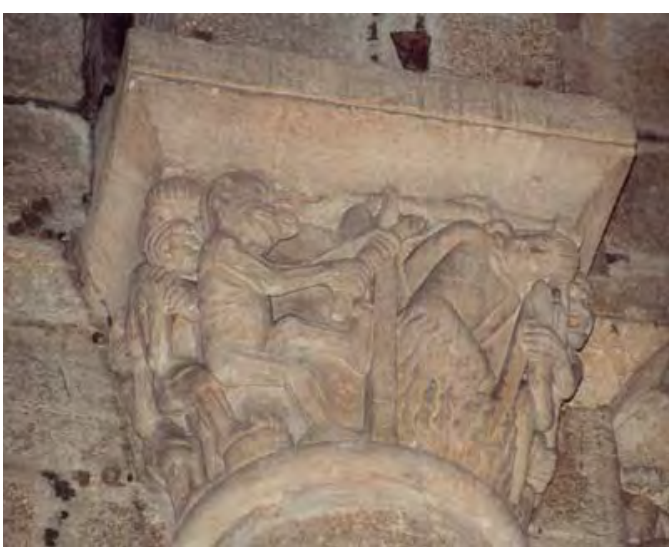

Fig. 34. Catedral de Santiago, brazo norte del crucero: Maestro de Conques o de las Tentaciones, Capitel del Avaro, 1101-1103.

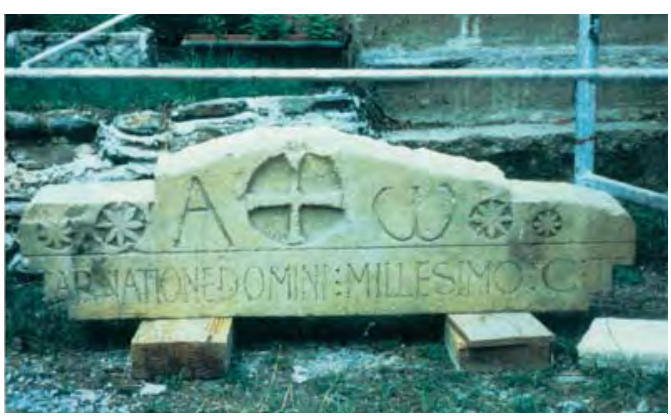

Fig. 35. Dintel pentagonal de las dependencias claustrales de la abadía de Conques, 1100. Encontrado en una casa de Molinols, en las cercanías de Conques.

\section{En Compostela, el Maestro de}

Conques tuvo que enfrentarse a un reto: pasar del formato de narración corrida en la cesta del capitel, que lo había caracterizado en Conques, al desarrollo de

\footnotetext{
94 En la crónica de la abadía se afirmaba que «Bego venerabilis, qui claustrum contruxit, multas reliquias in auro posuit, textus evangeliorum fieri fecits (G. Desjardins, Cartulaire de l'abbaye de Conques de Rouergue, Documents historiques Publiés par la Société de l'École de Chartes, Paris, 1879, p. XLIV), mientras que los hexámetros leoninos del epitafio de la tumba de dicho abad proclaman: «HOC PERAGENS CLAVSTR/ VM: QVOD VERSVS/ TENDIT AD AUSTRVM» (R. Favreau, Corpus des Inscriptions de la France Médiévale, vol. 9, Poitiers, 2002, pp. 34-36).
}

95 Castińeiras, «Didacus Gelmirius», p. 79. 


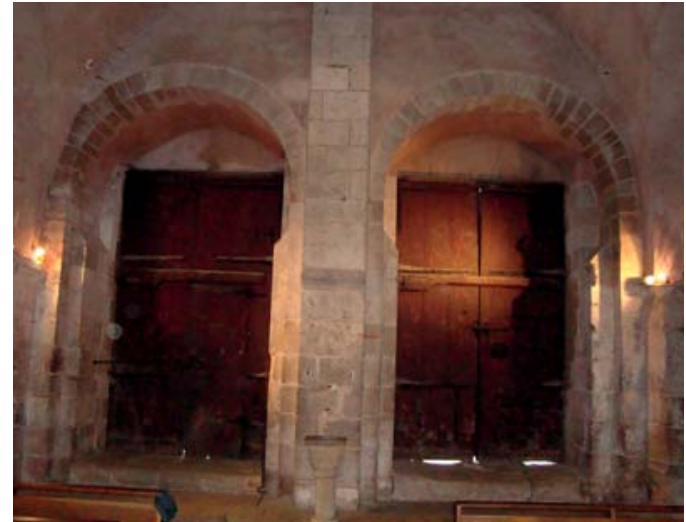

Fig. 36. Conques (Aveyron), Santa Fe, contrafachada con la bífora.

lastras-friso pensadas para un tímpano. De hecho, tras la experiencia compostelana, junto al Maestro de la Traición, pudo haber vuelto a Conques en el viaje que Diego Gelmírez realiza, camino de Cluny, por tierras de Francia en 1105, donde sabemos que al menos estuvo en Cahors. Allí ambos pudieron incorporarse al taller que entonces estaba realizando su magnífico Portal Occidental y transmitir una lección derivada de su frustrada experiencia compostelana: la de realizar un inmenso tímpano cubierto de relieves-friso en vez de dividirlo en pequeñas lunetas y frontispicio. Así, en Conques, obviaron la estructura bífora que todavía se observa desde el interior (fig. 36) y la disimularon, en el exterior, recubriéndola con una superficie uniforme para la narración, en la que la localización correspondiente a los tímpanos queda patente en los dinteles pentagonales de la Jerusalén Celeste y del Infierno. De esta manera, se superaban las trabas de la escultura arquitectónica — dependiente de los marcos- y se apostaba por una superficie relivaria.

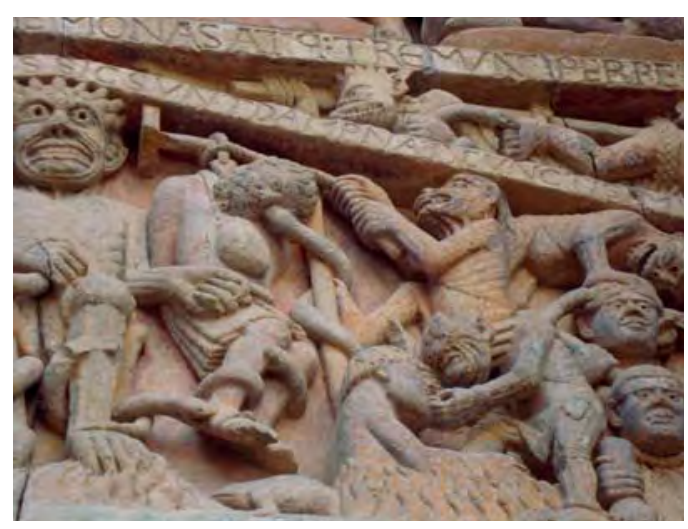

Fig. 37. Conques (Aveyron), Santa Fe, Portal Occidental: tímpano, lado derecho, Infierno, Castigo de la Avaricia, ca. 1103-1110.
La dependencia del portal galo de la experiencia previa del Maestro de Conques en Platerías se ve en la simple comparación entre el capitel del avaro en Compostela y el mismo castigo en el Portal Occidental de Conques (fig. 37). Este y otros muchos detalles han sido ampliamente comentados en la historiografía al uso con el objeto de demostrar la conexión entre ambos obradores, entre ellos el Cristo de las Tentaciones con el San Pedro de 
la procesión de los elegidos, el mutuo gusto por los tituli epigráficos así como la profusa presencia de ángeles trompeteros y ángeles que portan coronas. Por último, a este nudo de relaciones, recientemente he incorporado un nuevo punto de referencia para fechar el Portal Occidental a inicios del siglo xII: el Libro de Milagros de Santa Fe de Selestat (ca. 1105), un priorato de Conques en Alsacia, que incorpora dos himnos dedicados a Santiago y presenta una inicial miniada con Santa Fe, Caprasio y Daciano que recuerda a la procesión de los elegidos del Portal Occidental ${ }^{96}$.

Volviendo a Platerías, por lo que respecta al frontispicio de la fachada, este parece haber sido pensado, en origen, para un Apostolado-friso, una tipología que gozará de una gran fortuna en el Románico hispano, con ejemplos en San Quirce de Burgos — puerta norte_- San Pedro de Tejada, Santiago de Carrión, Moarves y Santa María de Ripoll. De hecho, todavía se conservan nueve de estos primitivos doce apóstoles, removidos y repartidos ahora en dos grupos en el friso. Con este Apostolado, pensado para colocarse de forma holgada bajo doce de los diecisiete canes que enmarcan la fachada, sucedió posiblemente lo mismo que con los tímpanos: a la hora de su definitiva sistematización se le añadió el grupo central de la Transfiguración, el cual habría sido pensado para la Puerta Occidental. La inclusión de estas lastras tuvo que ser, de hecho, muy temprana, quizá hacia 1111 si leemos — tal y como sugirió J. Williams— la inscripción del Santiago entre cipreses "ANF(us) REX» (fig. 1) como una alusión a la coronación de Alfonso Raimúndez en la catedral compostelana ${ }^{97}$. Se trataría, pues, de una alteración del proyecto inicial casi inmediata o quizás en plena obra con vistas a la ceremonia de la coronación real y no fruto de la restauración tras el incendio de 1116-1117, como hasta ahora se había defendido.

La puerta se vio además afectada por dos asedios. El primero de estos es suficientemente conocido por la historiografía artística: se trata del asalto a la catedral de los compostelanos en 1116-1117. Según la Historia Compostelana, dicho hecho infringió graves daños al conjunto jacobeo, al incendiar los andamios y cimbras de madera de la catedral en construcción y dejar el primitivo Palacio de

96 Castiñeiras, «Da Conques a Compostella».

97J. Williams, «Spain or Tolouse a Half Century Later Observations on the Chronology of Santiago de Compostela», en Actas del XXIII Congreso Internacional de Historia del Arte, vol. I, Granada, 1976, pp. 557-567, espec. p. 561. 
Gelmírez en un estado que obligó al obispo a plantearse el traslado de su residencia del lado sur al norte ${ }^{98}$. Tal y como señala F. López Alsina, no debe por ello extrañar que en dicha revuelta los ciudadanos asediasen, saqueasen y prendiesen fuego al escenario de Platerías, pues este era por antonomasia la expresión del poder feudal ${ }^{99}$. ¿Tendría la fachada del palacio algún tipo de decoración escultórica en consonancia con la puerta meridional de la catedral? No podemos responder, pero quizás alguna de las piezas que hoy ornan Platerías formó en origen parte de los muros de la residencia del obispo. La memoria del lugar del primer palacio todavía subsistía en la segunda mitad del siglo xv. De hecho, en la Crónica de Santa María de Iria, que narra un segundo cerco y asedio que sufrió la catedral en 1466 , en el cual se puso de nuevo fuego a Platerías ${ }^{100}$, se hace una referencia al primitivo palacio de Gelmírez, «aos quaes agora dicen os paaços vellos» ${ }^{101}$.

La visión anticuaria de M. Castellá y Ferrer, que veía la decoración de las portadas compostelanas como fruto de la reutilización de piezas procedentes de distintas partes del templo, adquirió todo su sentido con la destrucción de la Porta Francigena entre 1757 y 1758. Es entonces cuando, a causa quizá de ese mismo sentido anticuario con el que se explicaba las fachadas del transepto, muchas de sus lastras fueron encastradas en los contrafuertes y friso de la portada meridional, obligando a remover de nuevo algunas piezas, en particular el colegio apostóli$\mathrm{Co}^{102}$. La última intervención sobre esta portada-palimpsesto fue protagonizada por A. López Ferreiro, quien en 1884 incluyó en el frontispicio seis profetas del coro del taller del Maestro Mateo así como el relieve con la Expulsión de Adán y Eva procedente de la Rúa de Pitelos.

\footnotetext{
98 Hс, II, 25, trad. cit., pp. 345-346.

99 López Alsina, «Implantación urbana», p. 51.

100 "poseron fogo ena Prataria et en derredor de toda a egllesia et ardeu todo», en J. Carro García (ed.), Coronica de Santa Maria de Iria (Códice gallego del siglo XV), Santiago, 1951, p. 46 (en adelante Coronica).

101 Coronica, p. 86.

102 Cfr. Moralejo, «La primitiva puerta norte», pp. 623-624.
} 